\title{
Investment, R\&D and Financial Constraints in Britain and Germany
}

Stephen Bond, Dietmar Harhoff and John Van Reenen 


\begin{abstract}
This paper tests for the importance of cash flow on investment in fixed capital and R\&D using firm-level panel data in two countries between 1985 and 1994. For German firms, cash flow is not informative in simple econometric models of fixed investment or R\&D. In identical specifications for British firms, cash flow is informative about investment, although not about the level of $R \& D$ spending conditional on the $R \& D$ participation decision. In the UK, we also find that investment is less sensitive to cash flow for R\&Dperforming firms, and that cash flow predicts whether firms perform R\&D or not. We confirm that these differences do not simply reflect a greater role for current cash flow in forecasting future sales. These results suggest that financial constraints are more significant in Britain, that they affect the decision to engage in $R \& D$ rather than the level of $R \& D$ spending by participants, and that consequently the British firms that do engage in $\mathrm{R} \& \mathrm{D}$ are a self-selected group where financing constraints tend to be less binding.
\end{abstract}

Keywords: Investment, R\&D, cash flow, financial constraints, panel data

JEL classification: L13, 031, C25.

The Centre for Economic Performance is financed by the Economic and Social Research Council. This paper was produced as part of the Centre's Productivity and Innovation Programme.

\title{
Acknowledgments
}

We would like to thank Charles Calomiris, Jason Cummins, Bronwyn Hall, Charles Himmelberg, Glenn Hubbard, Charles Hulten, Jacques Mairesse, Colin Mayer, and participants in seminars in CEMFI, Columbia, Essex, LSE, NYU,Oxford, Paris, SOAS, and Toulouse for helpful comments. Financial support from the Anglo-German Foundation and the ESRC is gratefully acknowledged. The usual disclaimerapplies.

Stephen Bond is a Programme Director, Institute for Fiscal Studies, London and a Research Fellow at Nuffield College, Oxford. Dietmar Harhoff is a Professor at the University of Munchen and a Research Fellow at CEPR. John Van Reenen is Director of the Centre for Economic Performance and Professor of Economics, London School of Economics.

Correspondence: j.vanreenen@1se.ac.uk Centre for Economic Performance, London School of Economics, Houghton Street, London WC2A 2AE

Published by

Centre for Economic Performance

London School of Economics and Political Science

Houghton Street

London WC2A $2 \mathrm{AE}$

All rights reserved. No part of this publication may be reproduced, stored in a retrieval system or transmitted in any form or by any means without the prior permission in writing of the publisher nor be issued to the public or circulated in any form other than that in which it is published.

Requests for permission to reproduce any article or part of the Working Paper should be sent to the editor at the above address.

(C) S. Bond, D. Harhoff and J. Van Reenen, submitted 2003

ISBN 0753016737

Individual copy price: $£ 5$ 


\section{Introduction}

Are financial constraints a significant determinant of company investment activities? Numerous papers have addressed this question in the last decade. ${ }^{1}$ This paper is novel in two principal respects. First, we investigate whether the impact of financial variables differ between firms in Britain and Germany. Second, we investigate whether the impact of financial variables differ between investment in fixed capital and investment in research and development (R\&D). ${ }^{2}$ Alfred Marshall (1919, p.347) was neither the first, nor last, to draw critical comparisons between the system of finance for innovation in Britain relative to that in Germany. Despite this interest there have been no systematic attempts to exploit firm level information on R\&D investment and cash flow to identify any differences in the importance of liquidity constraints across the two nations.

Testing for financial constraints is intrinsically difficult. Financial variables such as cash flow contain information about expected future profitability which may be relevant for investment decisions even under the null hypothesis of perfect capital markets. Recent econometric tests have relied on finding differential sensitivity to cash flow between sub-samples of firms that are thought to be differentially affected by financial constraints a priori; and/or on structural econometric models which control for the influence of expected profitability under particular, usually highly restrictive, assumptions. There are at least two major problems with these methodologies. First, the allocation of firms to 'constrained' and 'unconstrained' regimes is often based on outcomes which, at least in part, are chosen endogenously by firms (e.g. dividend payments, employment size, corporate structure). Second, as Kaplan and Zingales (1997) have forcefully noted, even results based on structural models (e.g. Q models, Euler equations) have generally

\footnotetext{
${ }^{1}$ See Schiantarelli (1996) and Hubbard (1998) for recent surveys.

${ }^{2}$ There have been a few previous studies investigating financing constraints and R\&D (see Hall (2002) for a survey). Hall (1992), Himmelberg and Peterson (1994), Hao and Jaffe (1993)) focus on the US and Harhoff (1998) uses German data. Mulkay et al (2001) compare France and the US whilst Hall et al. (1999) present comparative results for France, Japan and the US. Bhagat and Welch (1995) find larger cash flow effects on R\&D for British and US firms than other G7 countries.
} 
found some sensitivity to cash flow even for the sub-samples of supposedly 'unconstrained' firms. At the same time, recent evidence of lumpy and irreversible adjustment has cast doubt on the specification of most existing structural models. ${ }^{3}$

Companies in Britain and Germany operate under strikingly different financial systems. To the extent that financial constraints on investment expenditures result from a cost premium for external sources of finance, these national differences may be associated with a difference in the significance of financial constraints. This cost premium could reflect asymmetric information and conflicts of interest between shareholders, managers and suppliers of outside finance. Share ownership in Germany tends to be more concentrated than in Britain, which may mitigate asymmetric information and conflicts of interest between shareholders and managers. Bank representation on supervisory boards and long-term repeated relationships between banks and firms in Germany may mitigate asymmetric information between lenders and borrowers. Large German firms are more likely to remain unquoted, hostile takeovers are extremely rare, and dividend payout ratios tend to be both lower and less rigid in German firms than in British firms. ${ }^{4}$ Many economic historians have suggested that Britain's financial system may be less conducive to long-term investment, and linked this to Britain's relative economic decline in the 20th Century. ${ }^{5}$ If these differences between national financial systems are truly exogenous and related to the impact of financial constraints, this variation offers a potentially compelling source of identification.

Why look at R\&D as well as fixed investment? There are good reasons to believe that some types of investment are more likely to be subject to financial constraints than others. Investments in intangible assets tend to be both riskier and harder to collateralize than investment in fixed assets; they may therefore be more prone to financing

\footnotetext{
${ }^{3}$ See Cabellero (1997) for a review.

${ }^{4}$ See Edwards and Fischer (1994) for evidence on share ownership, Franks and Mayer (1990) for evidence on takeovers, and Correia da Silva (1996) for evidence on dividends.

${ }^{5}$ See Gerschenkron (1968) for a classical exposition or Hutton (1995) for a more recent re-statement of this position.
} 
constraints. In addition, the very act of seeking outside support for an R\&D project could leak information to rivals and therefore reduce the prospective value of innovation. The disappointing growth of aggregate $\mathrm{R} \& \mathrm{D}$ spending in Britain over the last twenty years, compared to aggregate R\&D spending in other OECD countries (see Section 2), is often blamed on problems in financing $R \& D$ investment.

A small literature has emerged which does suggest that company R\&D spending is sensitive to cash flow, but the results are often weak. This is unsurprising. Two key features of R\&D investment are that establishing a R\&D programme involves significant sunk costs, and large fluctuations in the level of spending in existing research programmes are very costly. ${ }^{6}$ Financial constraints, if they are significant at all, may manifest themselves more in the decision to set up R\&D facilities, rather than in decisions about the year to year levels of spending in existing research programmes. We therefore consider the R\&D 'participation' decision, as well as the level of R\&D spending by those companies that do engage in $\mathrm{R} \& \mathrm{D}$. We also consider the relationship between fixed investment and cash flow separately for R\&D performing and non-R\&D performing companies. In each case we believe that the contrast between British firms and German firms is likely to be informative. For example, if the UK financial system makes it more expensive for firms to raise external finance for $R \& D$ investment, those firms that do engage in $R \& D$ may consist predominately of firms who are confident that they can finance their $R \& D$ commitments from internal sources. ${ }^{7}$ In this case financial constraints would tend not to be binding for these companies, so the fixed investment of R\&D performing firms may display lower sensitivity to cash flow than the fixed investment of non-R\&D performing firms in Britain. However if financial constraints are not significant for German companies, we should find no cash flow sensitivity in the

\footnotetext{
${ }^{6}$ Around sixty percent of $\mathrm{R} \& \mathrm{D}$ spending goes on the wages of $\mathrm{R} \& \mathrm{D}$ personnel. These are generally highly skilled workers, for whom there are large hiring, firing and training costs.

${ }^{7}$ In other words, having 'deep pockets' may be an important consideration in the R\&D participation decision (Schumpeter, 1942).
} 
investment behaviour of either the $R \& D$ performing firms or the non-R\&D performing firms in Germany.

The plan of the paper is as follows. In Section 2 we set the scene by examining aggregate trends in fixed investment and R\&D in Britain and Germany, and we describe the firm level datasets that we have compiled and used in our analysis. Section 3 outlines some simple econometric models of fixed investment and $\mathrm{R} \& \mathrm{D}$ which we use in this comparison. Section 4 contains the main empirical results, where we first examine fixed investment and $R \& D$ equations for R\&D performing firms in both countries. We then estimate fixed investment equations for samples which pool together both R\&D and non-R\&D performing firms and test whether there is a differential sensitivity to cash flow between R\&D performers and non-R\&D performers. Section 5 considers a series of potential criticisms concerning the interpretation of the cash flow variable, estimates of the R\&D participation decision, the production function, and measurement issues. Section 6 offers some concluding comments.

In short, our preferred specifications show sensitivity of fixed investment to cash flow for British companies but not for German companies. The level of R\&D spending by REDD performers is not sensitive to cash flow in either country. Within Britain there is greater sensitivity of fixed investment to cash flow for non-RED performing companies than for RESD performing companies, and the RESD performing companies are significantly more profitable. Within Germany, we do not find these differences. These findings are robust to a variety of alternative interpretations of the cash flow measure. This evidence is consistent with the hypothesis that British firms face significant financial constraints, and suggests that the British financial system may discourage some companies from engaging in $\mathrm{R} \& \mathrm{D}$. 


\section{Aggregate trends and company data sets}

The company datasets for the two countries are obtained from different sources. For the UK the data is drawn from the Datastream on-line service which covers all companies quoted on the UK stock market. R\&D data is available for some companies since the early 1970s, but for these companies R\&D disclosure was completely voluntary. Changes to the accounting conventions governing R\&D disclosure after 1985 mean that a representative sample is only available in later years. For Germany changes in disclosure requirements took effect from 1987 and we use R\&D information from the Bundesanzeiger supplemented by other sources of accounting data to construct the firm level dataset. This includes both quoted and unquoted AGs (stock companies) and GmbHs (limited liability corporations), which is important in the German context where a lot of large R\&D performing firms are not quoted on the stock market. ${ }^{8}$ For each country, we obtain two samples. The first includes essentially all the large firms who report $R \& D$ expenditures. The second sample also includes firms who did not report $R \& D$, and for which we were able to verify that they were not performing $R \& D$ according to standard definitions. The Data Appendix has a full description of the construction of both databases.

We attempt to use variables that are comparable across countries, even though the national accounting definitions are not precisely the same. The main variables we use are flows of fixed investment, R\&D investment, sales, gross operating profits, and cash flow. Investment spending is obtained from the sources and uses of funds account, and not inferred from changes in the balance sheet. We use real sales as a proxy for output. A measure of the stock of capital at current replacement cost was estimated from the flow data on investment using a standard perpetual inventory method, in a similar way

\footnotetext{
${ }^{8}$ Although we have two more years of data for the UK (1985 and 1986) than Germany there are fewer British firms in the pre-1989 period. Thus the overall sample sizes are roughly the same across the two countries which is an advantage when making inferences based on common significance levels.
} 
for each sample (see Data Appendix for more details).

Before describing the firm level data in more detail, it is worthwhile looking at some aggregate comparisons across time and between countries for $R \& D$ and fixed investment. ${ }^{9}$ Table 1a contains information on total gross fixed capital formation (GFCF) as a proportion of GDP for the UK and Germany since 1960. The top row shows clearly that Germany invested more of its GDP throughout the period 1960-1993. The second row excludes housing investment. This accounts for part of the difference between the countries, although not all of it (cf. Cabinet Office, 1996). The final row considers only machinery and equipment investment and this again narrows the gap, although Germany still invests more in the later period.

Table 1a: Fixed Investment as \% of GDP

\begin{tabular}{ccccccc}
\hline \hline & $1960-93$ & $1960-93$ & $1960-79$ & $1960-79$ & $1980-93$ & $1980-93$ \\
& UK & GER & UK & GER & UK & GER \\
Total GFCF & 18.2 & 22.4 & 18.6 & 23.7 & 17.4 & 20.4 \\
Total GFCF (exc. housing) & 14.4 & 15.9 & 14.8 & 16.7 & 13.7 & 14.5 \\
Machinery and Equipment & 8.4 & 8.7 & 8.7 & 8.7 & 8.0 & 8.6 \\
\hline \hline
\end{tabular}

Source: OECD Historical Statistics (1995)

Table 1b: R\&D as \% of GDP

\begin{tabular}{ccccccc}
\hline \hline & $1973-93$ & $1973-93$ & $1973-79$ & $1973-79$ & $1980-93$ & $1980-93$ \\
& UK & GER & UK & GER & UK & GER \\
BERD/GDP & 1.4 & 1.7 & 1.4 & 1.4 & 1.4 & 1.9 \\
\hline \hline
\end{tabular}

Source: OECD/DSTI ANBERD (1995)

\footnotetext{
${ }^{9}$ See Bond and Jenkinson (1996) and Van Reenen (1997) for a more detailed international comparison across countries for investment and $\mathrm{R} \& \mathrm{D}$ respectively.
} 
Table 1c: Financing of BERD, 1989

\begin{tabular}{ccccc}
\hline \hline & UK & GER & EU & OECD \\
& & & & \\
Industry Own Financed & 69.5 & 86.0 & 78.8 & 79.6 \\
Overseas Financed & 13.4 & 2.7 & 6.9 & $\mathrm{n} / \mathrm{a}$ \\
Government Financed & 17.2 & 11.3 & 14.4 & 18.0 \\
\hline \hline
\end{tabular}

Source: OECD Main Science and Technology Indicators (1996)

Table $1 \mathrm{~b}$ attempts a similar kind of analysis for $\mathrm{R} \& \mathrm{D}$ conducted by the business sector. The proportion of GDP devoted to business expenditure on R\&D (BERD) is higher in Germany than Britain, particularly in the 1980s compared to the 1970s. A final interesting fact is that domestic industry finances a much lower proportion of business R\&D spending in the UK than in Germany (see Table 1c). The government actually finances a larger proportion of business enterprise R\&D in the UK than in Germany (notably in military R\&D). It is clear then that domestic, privately funded business $\mathrm{R} \& \mathrm{D}$ is considerably lower in Britain as a proportion of GDP than in Germany.

Turning now to the company data, Table 2 contains some simple descriptive statistics for the sample of firms who reported R\&D in 1992. ${ }^{10}$ On average the British and German firms are of similar size (as measured by employment). Although the mean and median German firm is slightly larger, British firms are larger at the upper tail of the distribution. These are typically large firms, even for firms quoted on the UK Stock Exchange, a point that will be returned to in discussing the empirical results. In terms of sales, the British firms are slightly larger at the mean, but German firms are larger at the median. So in terms of size distribution, our two samples are reasonably well matched.

Investment comparisons are also made in Table 2 . These are more difficult because the investment figures in German company accounts do not include fixed capital acquired

\footnotetext{
${ }^{10}$ We report descriptives for a single year where we have a large cross section of firms in both countries. Very similar results are obtained for other years.
} 
through acquisitions of new subsidiary companies, whereas the British figures do. The 'wide definition' of UK investment (including acquisitions) suggests that British and German firms look very similar, even that UK firms invest slightly more of their sales than their German counterparts at the mean. Excluding these acquisitions (the "narrow definition') reveals that at both the mean and the median UK firms invest slightly less than German firms in direct purchases of fixed capital. This appears broadly consistent with the aggregate figures for machinery and equipment in Table 1a. ${ }^{11}$

Typically, researchers using R\&D data have constructed a cash flow measure that adds back R\&D expenditures to conventionally measured cash flow, since most R\&D costs are expensed in company accounts (e.g. Hall 1992; Himmelberg and Peterson, 1994). In Table 2 the ratio of this cash flow measure (i.e. gross of R\&D) to the capital stock appears similar across the two countries. This disguises the fact that German firms have much higher $R \& D$ and somewhat lower cash flow net of $R \& D$ costs than UK firms. German corporations are much more R\&D intensive than British companies. The average German company in the sample invests about $6 \%$ of sales in $\mathrm{R} \& \mathrm{D}$, compared to $3 \%$ in the UK. The aggregate figures for this period are broadly consistent with this 'R\&D gap'12. This consistency between the OECD data and the company accounting data is reassuring as although the accounting definitions of $R \& D$ in both countries are based on the common Frascati manual definition, it may be that German accountants take a wider definition of view of what constitutes $R \& D^{13}$. The ' $R \& D$ gap' between

\footnotetext{
${ }^{11}$ The narrow measure is more comparable to the aggregate figures, since one firm acquiring capital from another does not raise aggregate investment. The wide measure is probably more suitable for models of company investment, but this is not available for our German sample. In the empirical work reported below we use the wide definition of investment for the UK, where acquisitions are far more important than in Germany. In fact our UK results were similar whichever measure was used (see Section 5.5).

${ }^{12}$ Industrially funded business R\&D intensities are only about $60 \%$ higher in Germany (combine Tables $1 \mathrm{~b}$ and 1c). The difference between the firm level and the aggregate figures arises mainly from the fact that the firm level figures refer to all $R \& D$ regardless of where it was conducted, whereas the aggregate figures are based on all R\&D conducted within a territorial area.

${ }^{13}$ In the empirical specifications the inclusion of firm specific effects should help mitigate this sort of measurement error.
} 
Britain and Germany is not simply due to a different industrial composition as Table A1 in the Appendix shows that even within industries, British firms have lower R\&D intensities. Neither can it be explained by tax incentives, as R\&D is treated in a very similar manner for tax purposes in the two countries - essentially it can all be expensed against corporate tax liabilities (see Bloom et al, 1998, for more details of the tax treatment of $\mathrm{R} \& \mathrm{D}$ across countries).

Table 3 looks at the second sample we have constructed which includes non-R\&D performing firms. We focus here on industries with above median $R \& D$ intensity and label these 'high tech' industries. Comparing R\&D and non-R\&D firms across all sectors could be misleading because there is practically zero $R \& D$ in many industries. These 'high tech' sectors include some industries which are not typically thought of as being very science-based (such as motor vehicles), but our samples are not large enough to adopt a narrow classification.

The first striking thing about Table 3 is that $R \& D$ performing firms ("R\&D $>0$ ") tend to be both larger and more profitable (as reflected in cash flow) in both countries. The difference in profitability is greater in Britain than Germany, however. The difference in the cash flow ratios (net of $R \& D$ costs) between $R \& D$ performers and non- $R \& D$ performers is $0.091(=0.254-0.163)$ in the UK and $0.028(=0.143-0.115)$ in Germany. Obviously this difference would be even greater had we measured cash flow gross of $R \& D$ costs. It is also interesting to note that far more firms in our sample perform $R \& D$ in Germany (83\%) than in the UK (53\%). This suggests that cash flow may be important in the decision to set up an $\mathrm{R} \& \mathrm{D}$ programme (the participation decision) as well as the ongoing decision of how much to spend in existing R\&D programmes.

As a final piece of preliminary analysis we consider a simple 'difference in differences' estimator. We are seeking to identify financial constraints from the correlation of differences in investment with differences in cash flow (to remove fixed effects). Recognizing that there may be a correlation for reasons unrelated to financial constraints we 
are also using the difference in this correlation across different countries. To illustrate this we pooled the data across all firms in both countries in all years and ran a simple model where the rate of investment in fixed capital $\left(I_{t} / K_{t-1}\right)$ was regressed against sales growth $\left(\Delta y_{t}\right)$ and cash flow $\left(C / K_{t-1}\right)$. The model is estimated in first differences and also includes a dummy for the $U K$ and each time period. As expected, the results from this model showed that sales growth and cash flow are highly correlated with investment, and that British firms had slower growth in investment over this time period.

$$
\begin{aligned}
\Delta\left(I_{t} / K_{t-1}\right) & =-.016(.006) U K+.256(.036) \Delta\left(C_{t} / K_{t-1}\right)+.053(.016) \Delta \Delta y_{t}+\text { time dummies } \\
(t & =1987, . ., 1994 ; N T=1687 ; \text { robust standard errors } ; O L S) .
\end{aligned}
$$

Of more interest, however, is the interaction term between cash flow and the $U K$ dummy. This interaction term tests whether investment is more sensitive to cash flow in Britain than in Germany. Including this as an extra term generated the following results:

$$
\begin{aligned}
\Delta\left(I_{t} / K_{t-1}\right)= & -.009(.006) U K+.137(.031) \Delta\left(C_{t} / K_{t-1}\right)+.388(.090)\left[U K * \Delta\left(C_{t} / K_{t-1}\right)\right]+ \\
& .049(.016) \Delta \Delta y_{t}+\text { time dummies }
\end{aligned}
$$

Consistent with the view that British firms display more sensitivity to cash flow, the coefficient on this interaction term is positive and highly significant. This remains so when we add further interaction terms between the UK dummy and sales growth, and with the time dummies. On one level the paper is mainly concerned with probing the robustness of this interaction effect.

Despite the interest of these descriptives, one may have good reason to be sceptical about drawing any straightforward conclusions about financial constraints. We have 
done nothing here to control for a whole host of data and econometric problems. The next section confronts these problems in a more explicit econometric framework. 
Table 2: Descriptive Statistics for R\&D Performing firms

\begin{tabular}{|c|c|c|c|c|c|c|}
\hline & & Mean & s.d. & Q25 & Q50 & Q75 \\
\hline \multirow{2}{*}{$\begin{array}{l}\text { Employment } \\
(1000 \mathrm{~s})\end{array}$} & $U K$ & 16.134 & 38.551 & 0.645 & 2.142 & 10.153 \\
\hline & $G E R$ & 16.538 & 47.823 & 0.800 & 2.422 & 7.570 \\
\hline Sales & $U K$ & 1.361 & 4.314 & 0.038 & 0.122 & 0.659 \\
\hline$(£ m)$ & $G E R$ & 1.109 & 3.174 & 0.045 & 0.167 & 0.498 \\
\hline \multirow{3}{*}{$\begin{array}{l}(I / Y)_{t}-\text { narrow } \\
(I / Y)_{t}-\text { wide }\end{array}$} & $U K$ & 0.053 & 0.051 & 0.029 & 0.042 & 0.062 \\
\hline & $U K$ & 0.064 & 0.063 & 0.031 & 0.046 & 0.075 \\
\hline & $G E R$ & 0.058 & 0.054 & 0.031 & 0.049 & 0.066 \\
\hline \multirow[t]{2}{*}{$I_{t} / K_{t-1}$} & $U K$ & 0.137 & 0.113 & 0.070 & 0.105 & 0.162 \\
\hline & $G E R$ & 0.119 & 0.085 & 0.069 & 0.103 & 0.150 \\
\hline \multirow[t]{2}{*}{$\left(R \& D_{t}+\operatorname{Cash}_{t}\right) / K_{t-1}$} & $U K$ & 0.319 & 0.256 & 0.154 & 0.230 & 0.426 \\
\hline & $G E R$ & 0.311 & 0.293 & 0.155 & 0.236 & 0.359 \\
\hline \multirow[t]{2}{*}{$\operatorname{Cash}_{t} / K_{t-1}$} & $U K$ & 0.222 & 0.181 & 0.110 & 0.173 & 0.281 \\
\hline & $G E R$ & 0.171 & 0.171 & 0.077 & 0.126 & 0.207 \\
\hline \multirow[t]{2}{*}{$(R \& D / Y)_{t}$} & $U K$ & 0.028 & 0.036 & 0.006 & 0.016 & 0.032 \\
\hline & $G E R$ & 0.060 & 0.065 & 0.023 & 0.045 & 0.074 \\
\hline
\end{tabular}

NOTES:- These are taken for the sample of R\&D performing firms in 1992 (175 UK firms and 201 German firms) . 
Table 3 : Descriptive statistics for R\&D and non-R\&D Firms in the High

\section{Tech Sector}

\begin{tabular}{|c|c|c|c|c|c|c|}
\hline \multicolumn{7}{|c|}{ A. United Kingdom } \\
\hline & \multicolumn{3}{|c|}{$\mathrm{R} \& \mathrm{D}>0$} & \multicolumn{3}{|c|}{$\mathrm{R} \& \mathrm{D}=0$} \\
\hline & Mean & S.D. & Median & Mean & S.D. & Median \\
\hline $\begin{array}{l}\text { Employment } \\
\text { (1000s) }\end{array}$ & 10.663 & 28.080 & 1.392 & 1.927 & 5.673 & 0.595 \\
\hline $\begin{array}{l}\text { Sales } \\
(£ \mathrm{~m})\end{array}$ & 1.004 & 4.206 & 0.089 & 0.194 & 0.623 & 0.041 \\
\hline$(\mathrm{I} / \mathrm{Y})_{t}$ & 0.065 & 0.061 & 0.049 & 0.130 & 0.311 & 0.037 \\
\hline $\mathrm{I}_{t} / \mathrm{K}_{t-1}$ & 0.145 & 0.124 & 0.112 & 0.142 & 0.148 & 0.098 \\
\hline $\operatorname{Cash}_{t} / \mathrm{K}_{t-1}$ & 0.254 & 0.212 & 0.193 & 0.163 & 0.170 & 0.125 \\
\hline Firms & & 131 & & & 94 & \\
\hline \multicolumn{7}{|l|}{ B. Germany } \\
\hline & \multicolumn{3}{|c|}{$\mathrm{R} \& \mathrm{D}>0$} & \multicolumn{3}{|c|}{$\mathrm{R} \& \mathrm{D}=0$} \\
\hline & Mean & S.D. & Median & Mean & S.D. & Median \\
\hline $\begin{array}{l}\text { Employment } \\
\text { (1000s) }\end{array}$ & 18.600 & 55.60 & 2.552 & 1.051 & 5.311 & 0.457 \\
\hline $\begin{array}{l}\text { Sales } \\
(£ m)\end{array}$ & 1.182 & 3.410 & 0.161 & 0.066 & 0.096 & 0.023 \\
\hline$(\mathrm{I} / \mathrm{Y})_{t}$ & 0.058 & 0.037 & 0.052 & 0.072 & 0.051 & 0.064 \\
\hline $\mathrm{I}_{t} / \mathrm{K}_{t-1}$ & 0.123 & 0.080 & 0.108 & 0.139 & 0.087 & 0.128 \\
\hline $\operatorname{Cash}_{t} / \mathrm{K}_{t-1}$ & 0.143 & 0.120 & 0.114 & 0.115 & 0.099 & 0.122 \\
\hline Firms & & 202 & & & 42 & \\
\hline
\end{tabular}

NOTES:- These are taken for a sample of firms in 1992 in the high tech sectors of both countries. 


\section{Models of investment and R\&D}

In this paper the econometric specifications for fixed investment and $R \& D$ in the two countries are treated symmetrically. Different dynamics and costs of adjustment are allowed for (the estimated parameters can be different for British and German firms) but the specifications are identical for both countries. We also use the same basic framework to model both investment spending and R\&D spending, although details of the specification differ. This is primarily a matter of convenience. We want to compare common specifications across countries, rather than search for the best specification of investment and R\&D equations in each country. Nevertheless the approach has some disadvantages, which are discussed in more detail below.

The basic framework we use is an error correction model, which specifies a long-run or 'target' level of the capital stock (or stock of accumulated R\&D), but which allows a flexible specification of the adjustment dynamics to be estimated from the data. The main advantage of these models is that they are not rejected out of hand by the data, and the estimated models have reasonable long-run and short-run properties. This is in sharp contrast to more structural models such as Q models and Euler equations, which are often found to have the wrong signs on key explanatory variables or to imply implausibly slow speeds of adjustment ${ }^{14}$. The main disadvantage of the error correction models is that the estimated dynamics compound influences from both capital adjustment and expectations-formation processes. Thus the finding of a significant coefficient on cash flow cannot be interpreted directly as evidence of financing constraints. We return to this issue in Section 5, where we show that differences in the effect of cash flow between Britain and Germany cannot simply be explained by current cash flow being a better predictor of future sales. Furthermore, the cash flow effect is robust to the inclusion of

\footnotetext{
${ }^{14}$ There is some debate over whether the Q model can be "rescued" by using tax changes to generate instrumental variables for Q (see the survey by Hubbard, 1998, for example) or by defining Q based on analysts' forecasts rather than stock prices (see Bond and Cummins, 2001).
} 
a measure of analysts' forecasts (which proxy future demand expectations) in the R\&D participation equation.

\subsection{An error correction model of investment}

The error correction model we consider specifies the long-run desired level of the capital stock as a log-linear function of output and the user cost of capital. Letting $k_{i t}$ denote the (natural) $\log$ of the desired capital stock for firm $i$ in period $t, y_{i t}$ denote the $\log$ of output and $j_{i t}$ denote the log of the user cost of capital, we write the desired capital stock as

$$
k_{i t}=a+y_{i t}-\sigma j_{i t}
$$

In the absence of any adjustment costs or barriers to immediate adjustment, this would be the optimal capital stock for a profit maximizing firm with a constant returns to scale CES production function (cf. Cabellero, Engel and Haltiwanger (1995)). This formulation nests the possibility of a fixed capital-output ratio $(\sigma=0)$ and a CobbDouglas production function $(\sigma=1){ }^{15}$

In the presence of adjustment costs, for example, the actual capital stock will not adjust immediately to this target level. Recognizing that the adjustment process may be complex, we nest this expression for the long-run capital stock within a general autoregressive-distributed lag (ADL) dynamic regression model, and use a 'general-tospecific' specification search to let the data determine the relevant dynamics within our samples. For example, an $\operatorname{ADL}(2,2)$ model has the form

$$
\begin{aligned}
k_{i t}= & \alpha_{0}+\alpha_{1} k_{i, t-1}+\alpha_{2} k_{i, t-2}+\beta_{0} y_{i t}+\beta_{1} y_{i, t-1}+\beta_{2} y_{i, t-2} \\
& +\gamma_{0} j_{i t}+\gamma_{1} j_{i, t-1}+\gamma_{2} j_{i, t-2}+\varepsilon_{i t}
\end{aligned}
$$

\footnotetext{
${ }^{15}$ With $\sigma=1$, equation (3.1) describes the optimum capital stock in the Cobb-Douglas case, whether or not there are constant returns to scale. With this qualification noted, we will nevertheless refer to a long-run unit elasticity with respect to output as a test of constant returns to scale in what follows.
} 
where the long-run elasticity of capital with respect to output is given by $\left(\beta_{0}+\beta_{1}+\right.$ $\left.\beta_{2}\right) /\left(1-\alpha_{1}-\alpha_{2}\right)$.

It is convenient to re-parameterize the model in error correction form (cf. Bean, 1981), which separates out short-run and long-run effects. The corresponding error correction model has the form

$$
\begin{aligned}
\Delta k_{i t}= & \alpha_{0}+\left(\alpha_{1}-1\right) \Delta k_{i, t-1}+\beta_{0} \Delta y_{i t}+\left(\beta_{0}+\beta_{1}\right) \Delta y_{i, t-1}+\gamma_{0} \Delta j_{i t}+\left(\gamma_{0}+\gamma_{1}\right) \Delta j_{i, t-1} \\
& -\left(1-\alpha_{1}-\alpha_{2}\right)(k-y)_{i, t-2}+\left[\beta_{0}+\beta_{1}+\beta_{2}-\left(1-\alpha_{1}-\alpha_{2}\right)\right] y_{i, t-2} \\
& +\left(\gamma_{0}+\gamma_{1}+\gamma_{2}\right) j_{i, t-2}+\varepsilon_{i t} .
\end{aligned}
$$

Notice that the term in the (second) lagged level of output tests the restriction that the long-run elasticity of capital with respect to output is unity.

To implement this model using company panel data, we assume that variation in the user cost of capital can be controlled for using additive year-specific effects $\left(\mu_{t}\right)$ and firm-specific effects $\left(\eta_{i}\right)$. To investigate whether financial variables have explanatory power for investment, we include current and lagged terms in the ratio of cash flow to the beginning-of-period capital stock $\left(C_{i t} / K_{i, t-1}\right)$. Finally we use the approximation $\Delta k_{i t} \approx I_{i t} / K_{i, t-1}-\delta_{i}$, where $\delta_{i}$ is the (possibly firm-specific) depreciation rate, subsumed into the unobserved firm-specific effects $\left(\eta_{i}\right)$. Thus we obtain a model for the investment rate rather than the growth rate of the capital stock:

$$
\begin{aligned}
\left(\frac{I_{i t}}{K_{i, t-1}}\right)= & \mu_{t}+\rho_{1}\left(\frac{I_{i, t-1}}{K_{i, t-2}}\right)+\omega_{0} \Delta y_{i t}+\omega_{1} \Delta y_{i, t-1}+\theta(k-y)_{i, t-2} \\
& +\phi y_{i, t-2}+\psi_{0}\left(\frac{C_{i t}}{K_{i, t-1}}\right)+\psi_{1}\left(\frac{C_{i, t-1}}{K_{i, t-2}}\right)+\eta_{i}+\varepsilon_{i t} .
\end{aligned}
$$

We require $\theta<0$ to be consistent with 'error correcting' behaviour (i.e. a capital stock above its desired level is associated with lower future investment), and $\phi=0$ to be consistent with long-run constant returns to scale.

It is well known that significant coefficients on the cash flow variables in this type 
of model cannot be interpreted directly as evidence of financial constraints. ${ }^{16}$ In the presence of convex adjustment costs, for example, the current level of the capital stock would depend not just on current output and prices, as in (3.1), but also on the inherited level of the capital stock, and on expectations of future output and prices. ${ }^{17}$ To illustrate the implications as simply as possible, suppose that the desired capital stock in the absence of adjustment costs is proportional to output, and that the actual capital stock in the presence of adjustment costs is given by

$$
k_{i t}=\alpha k_{i, t-1}+\beta y_{i t}+\gamma E_{t}\left[y_{i, t+1}\right]
$$

where $E_{t}\left[y_{i, t+1}\right]$ denotes the expected value of $y_{i, t+1}$ given information in period $\mathrm{t}$. Clearly, if expectations of future output depend on financial variables as well as past output, then these financial variables would be significant in a reduced form model of investment, even in the absence of financing constraints. For example, if

$$
E_{t}\left[y_{i, t+1}\right]=\pi_{0} y_{i t}+\pi_{1} y_{i, t-1}+\pi_{2}\left(\frac{C_{i t}}{K_{i, t-1}}\right)+\pi_{3}\left(\frac{C_{i, t-1}}{K_{i, t-2}}\right)
$$

then we obtain the reduced form model

$$
k_{i t}=\alpha k_{i, t-1}+\left(\beta+\gamma \pi_{0}\right) y_{i t}+\gamma \pi_{1} y_{i, t-1}+\gamma \pi_{2}\left(\frac{C_{i t}}{K_{i, t-1}}\right)+\gamma \pi_{3}\left(\frac{C_{i, t-1}}{K_{i, t-2}}\right)
$$

which illustrates how these models compound influences from the structural adjustment process $(\gamma)$ and the expectations-formation process (the $\pi$ coefficients).

Whilst this is clearly the case for reduced form models, a similar problem will affect any structural models that are not correctly specified. Many studies have therefore focussed on differences in the coefficients on financial variables between different subsamples of firms. For this reason we will emphasize differences in the results on the cash

\footnotetext{
${ }^{16}$ See, for example, Fazzari, Hubbard and Petersen (1988). For more recent contributions ctiticising the interpretation of cash flow in investment equation see Kaplan and Zingales (1997), Gomes (2001) and Abel and Eberley (2002)

${ }^{17}$ See Nickell (1978), chapter 11, for example.
} 
flow terms between British firms and German firms, and between R\&D firms and nonR\&D firms in each country. However we will go one step beyond the common practice in the literature by investigating whether differences in the cash flow coefficients in the investment equations can be accounted for by differences in the ability of cash flow to predict future sales (i.e. by differences in the $\pi$ coefficients in VAR models of real sales).

\subsection{An error correction model of $R \& D$}

Our basic approach to modelling R\&D spending parallels our approach to modelling investment spending, as outlined above. We view R\&D spending as a flow which is adjusted to achieve some desired level of an underlying stock, in this case the stock of accumulated R\&D or 'knowledge'. The knowledge stock $\left(G_{i t}\right)$ is given conceptually by $G_{i t}=\left(1-\delta_{i}^{R}\right) G_{i, t-1}+R_{i t}$, where $R_{i t}$ is the current level of R\&D spending and $\delta_{i}^{R}$ is the (possibly firm-specific) rate at which research capital depreciates. Parallel to equation (3.3), this would suggest an error correction model for R\&D of the form

$$
\begin{aligned}
\Delta g_{i t}= & \alpha_{0}^{R}+\left(\alpha_{1}^{R}-1\right) \Delta g_{i, t-1}+\beta_{0}^{R} \Delta y_{i t}+\left(\beta_{0}^{R}+\beta_{1}^{R}\right) \Delta y_{i, t-1}+\gamma_{0}^{R} \Delta j_{i t}^{R}+\left(\gamma_{0}^{R}+\gamma_{1}^{R}\right) \Delta j_{i, t-1}^{R} \\
& -\left(1-\alpha_{1}^{R}-\alpha_{2}^{R}\right)(g-y)_{i, t-2}+\left[\beta_{0}^{R}+\beta_{1}^{R}+\beta_{2}^{R}-\left(1-\alpha_{1}^{R}-\alpha_{2}^{R}\right)\right] y_{i, t-2} \\
& +\left(\gamma_{0}^{R}+\gamma_{1}^{R}+\gamma_{2}^{R}\right) j_{i, t-2}^{R}+\varepsilon_{i t}^{R} .
\end{aligned}
$$

where $g_{i t}$ is the log of the stock of accumulated $\mathrm{R} \& \mathrm{D}$ and $j_{i t}^{R}$ is the user cost of capital for $R \& D$.

The main difference from the case of fixed investment, however, is that whilst company accounts contain some information on the value of the fixed capital stock, they contain no information on the value of the $R \& D$ capital stock. This need not be a serious problem if long time series were available on the R\&D expenditure flows, but for both British and German companies the available series on R\&D spending are generally short. For this reason we rely on a steady state approximation to 'measure' the stock of $R \& D$ capital, rather than trying to construct a direct estimate. 
For a firm in steady state (at growth rate $\nu_{i}$ ) we have $G_{i t}=\left(1+\nu_{i}\right) G_{i, t-1}$ so that

$$
\begin{aligned}
R_{i t} & =\left(\delta_{i}^{R}+\nu_{i}\right) G_{i, t-1} \\
& =\left(\frac{\delta_{i}^{R}+\nu_{i}}{1+\nu_{i}}\right) G_{i t}
\end{aligned}
$$

and

$$
r_{i t}=\ln \left(\frac{\delta_{i}^{R}+\nu_{i}}{1+\nu_{i}}\right)+g_{i t}
$$

where $r_{i t}$ is the log of R\&D expenditure (cf. Bean, 1981). If this steady state approximation is reasonable, we can replace $g_{i t}$ in equation (3.5) by the observed $r_{i t}$, provided we allow for a firm-specific intercept. In fact, our empirical specification is more general than this, and controls for some deviations of actual R\&D spending from its steady state level by the inclusion of year dummies and the autoregressive-distributed lag dynamics. Thus our error correction model for R\&D takes the form:

$$
\begin{aligned}
\Delta r_{i t}= & \mu_{t}^{R}+\rho_{1}^{R} \Delta r_{i, t-1}+\omega_{0}^{R} \Delta y_{i t}+\omega_{1}^{R} \Delta y_{i, t-1}+\theta^{R}(r-y)_{i, t-2} \\
& +\phi^{R} y_{i, t-2}+\psi_{0}^{R}\left(\frac{C_{i t}}{K_{i, t-1}}\right)+\psi_{1}^{R}\left(\frac{C_{i, t-1}}{K_{i, t-2}}\right)+\eta_{i}^{R}+\varepsilon_{i t}^{R} .
\end{aligned}
$$

As is the case of fixed investment, we require $\theta^{R}<0$ for error correcting adjustment, and $\phi^{R}=0$ for constant returns to scale.

We prefer this specification for $R \& D$, but not for fixed investment. This is partly because of the availability of fixed capital stock data, and partly because the steady state approximation is less likely to be reasonable in the case of investment: the investment series are typically less smooth than the $R \& D$ series. It should also be noted that we compared this approach with one where we explicitly measured the stock of accumulated R\&D capital using perpetual inventory procedures. We found that the latter approach did not yield sensible empirical results in the context of an error correction model.

\subsection{Estimation}

To estimate these dynamic regression models using panels containing many firms and a small number of time periods, we use a system GMM estimator developed by Arel- 
lano and Bover (1995) and Blundell and Bond (1998). This estimator controls for the presence of unobserved firm-specific effects and for the endogeneity of the current-dated explanatory variables. The system GMM estimator uses equations in first-differences, from which the firm-specific effects are eliminated by the transformation, and for which endogenous variables lagged two or more periods will be valid instruments provided there is no serial correlation in the time-varying component of the error terms. This is tested by examining tests for serial correlation in the first-differenced residuals (see Arellano and Bond, 1991). These differenced equations are combined with equations in levels, for which the instruments used must be orthogonal to the firm-specific effects. Obviously the level of the dependent variable must be correlated with the firm-specific effects, and we want to allow for the levels of all the explanatory variables to be potentially correlated with the firm-specific effects, so this rules out using the levels of any variables as instruments for the levels equations. However, Blundell and Bond (1998) show that in autoregressive-distributed lag models, first-differences of the series can be uncorrelated with the firm-specific effects provided that the series have stationary means. We therefore experimented with lagged differences of the variables as instruments for the levels equations.

The precise instruments that we use are reported in the notes to the tables below. Essentially we use lags of all the firm level variables in the model. Instrument validity was tested using a Sargan test of over-identifying restrictions, and by Difference Sargan comparisons to the GMM estimator which just uses the equations in first-differences. The system GMM estimators reported here generally produced more reasonable estimates of the autoregressive dynamics than the basic first-differenced estimators. ${ }^{18}$ This is consistent with the analysis of Blundell and Bond (1998), who show that in autoregressive models with persistent series, the first-differenced estimator can be subject to serious finite sample biases as a result of weak instruments, and that these biases can

\footnotetext{
${ }^{18}$ This was assessed by comparison to alternative estimators such as Within Groups and OLS levels, which are known to produce biased estimates of autoregressive parameters.
} 
be greatly reduced by the inclusion of the levels equations in the system estimator. We report results for a one-step GMM estimator, with standard errors and test statistics that are asymptotically robust to general heteroskedasticity ${ }^{19}$.

We believe the use of GMM system estimator goes a long way to deal with the problem of 'weak instruments' highlighted in much recent empirical work. Although the lack of 'external' instruments may be seen as a disadvantage, it is worth emphasizing that a major source of identification comes from the differences in the estimated coefficients across the two countries.

\section{Main Results}

We begin by reporting the results of the investment equation in Table 4 and then discuss the $\mathrm{R} \& \mathrm{D}$ equations in Table 5 . Column (1) in Table 4 contains the empirical results of estimating (3.4) for our sample of UK R\&D performing companies. It should be compared with column (4) which has an identically specified model for the German R\&D performing companies. For both countries we find evidence for a correctly signed error-correction term (the capital-output ratio) which is significant at conventional levels. There also appears to be some evidence that the speed of adjustment is faster in Britain than in Germany. The output growth terms are positive and significant in both countries. Furthermore, the diagnostic tests appear satisfactory with no evidence of second order serial correlation in the first-differenced residuals or rejection of the overidentifying restrictions in either country.

\footnotetext{
${ }^{19}$ Although a more efficient two-step GMM estimator is available, the asymptotic standard errors for the two-step estimator can be an unreliable guide for inference in finite samples. The system GMM estimates that we report are computed using DPD98 for GAUSS (see Arellano and Bond, 1998).
} 
Table 4: Fixed Investment Models

\begin{tabular}{lcccccc}
\hline \hline & $(1)$ & $(2)$ & $(3)$ & $(4)$ & $(5)$ & $(6)$ \\
$I_{t} / K_{t-1}$ & & & \multicolumn{5}{c}{ Germany } \\
& & $U K$ & \multicolumn{5}{c}{} \\
$I_{t-1} / K_{t-2}$ & -0.153 & -0.200 & -0.200 & 0.057 & 0.010 & 0.010 \\
& 0.082 & 0.084 & 0.073 & 0.066 & 0.071 & 0.060 \\
$\Delta y_{t}$ & 0.204 & 0.179 & 0.179 & 0.152 & 0.150 & 0.149 \\
& 0.089 & 0.089 & 0.081 & 0.050 & 0.051 & 0.044 \\
$\Delta y_{t-1}$ & 0.149 & 0.103 & 0.103 & 0.135 & 0.123 & 0.122 \\
& 0.064 & 0.054 & 0.055 & 0.037 & 0.049 & 0.045 \\
$\mathrm{C}_{t} / \mathrm{K}_{t-1}$ & - & 0.001 & - & - & -0.003 & - \\
& & 0.218 & & & 0.109 & \\
$\mathrm{C}_{t-1} / \mathrm{K}_{t-2}$ & - & 0.290 & 0.290 & - & 0.146 & 0.147 \\
& & 0.142 & 0.103 & & 0.095 & 0.100 \\
$(\mathrm{k}-\mathrm{y})_{t-2}$ & -0.187 & -0.141 & -0.142 & -0.099 & -0.085 & -0.084 \\
& 0.057 & 0.052 & 0.053 & 0.041 & 0.055 & 0.053 \\
& & & & & & \\
\hline Sargan (p-value) & 0.410 & 0.512 & 0.386 & 0.480 & 0.325 & 0.309 \\
Cash Flow terms (p) & - & 0.019 & 0.005 & - & 0.288 & 0.139 \\
LM (1) & -3.937 & -4.305 & -4.289 & -3.010 & -3.171 & -3.116 \\
LM (2) & -0.282 & -0.035 & -0.034 & -1.150 & -1.286 & -1.242 \\
Observations & 588 & 588 & 588 & 666 & 666 & 666 \\
Firms & 199 & 199 & 199 & 209 & 209 & 209 \\
\hline \hline
\end{tabular}

NOTES:- Asymptotically robust standard errors are reported below coefficients; estimation by GMM-SYSTEM using DPD98 package one-step results; full set of time dummies included; 'Sargan' is a Sargan-Hansen test of the overidentifying restrictions (p-value reported); 'Cash Flow terms' is a Wald Test of the joint significance of the two cash flow terms (p-value reported); 'LM (k)' is the test statistic for the presence of k-th order serial correlation in the first-differenced residuals, distributed $\mathrm{N}(0,1)$ under the null; in columns (1) and (4) instruments are $y_{t-2}$ to $y_{t-4}, \mathrm{I}_{t-2} / \mathrm{K}_{t-3}$ to $\mathrm{I}_{t-3} / \mathrm{K}_{t-4},(\mathrm{k}-\mathrm{y})_{t-2}$ to $(\mathrm{k}-\mathrm{y})_{t-3}$ in the differenced equations and $\Delta \mathrm{I}_{t-1} / \mathrm{K}_{t-2}, \Delta^{2} y_{t-1}$ in the levels equations; in columns (2),(3),(4) and (5) we also include $\mathrm{C}_{t-2} / \mathrm{K}_{t-3}$ to $\mathrm{C}_{t-3} / \mathrm{K}_{t-4}$ in the differenced equations. 
Table 5: R\&D Models

\begin{tabular}{lcccc}
\hline \hline \multirow{2}{*}{$r_{t}$} & $(1)$ & $(2)$ & $(3)$ & $(4)$ \\
& \multicolumn{2}{c}{$U K$} & \multicolumn{2}{c}{ Germany } \\
$\Delta r_{t-1}$ & -0.178 & -0.278 & -0.107 & -0.132 \\
& 0.129 & 0.101 & 0.065 & 0.060 \\
$\Delta y_{t}$ & 0.627 & 0.382 & 0.486 & 0.424 \\
& 0.214 & 0.240 & 0.169 & 0.186 \\
$\Delta y_{t-1}$ & 0.633 & 0.561 & 0.173 & 0.138 \\
& 0.314 & 0.220 & 0.063 & 0.069 \\
$\mathrm{C}_{t} / \mathrm{K}_{t-1}$ & - & 0.272 & - & 0.269 \\
& & 0.614 & & 0.216 \\
$\mathrm{C}_{t-1} / \mathrm{K}_{t-2}$ & - & 0.143 & - & -0.049 \\
& & 0.539 & & 0.184 \\
$(\mathrm{r}-\mathrm{y})_{t-2}$ & -0.132 & -0.159 & -0.070 & -0.064 \\
& 0.054 & 0.044 & 0.047 & 0.039 \\
& & & & \\
\hline Sargan (p) & & & & \\
Cash Flow terms (p) & & 0.347 & & 0.210 \\
LM (1) & -2.52 & -2.596 & -3.70 & -3.73 \\
LM (2) & -1.83 & -2.396 & 0.550 & 0.500 \\
Observations & 389 & 389 & 666 & 666 \\
Firms & 159 & 159 & 209 & 209 \\
\hline \hline
\end{tabular}

NOTES:- Asymptotically robust standard errors are reported below the coefficients; estimation by GMM-SYSTEM using DPD98 package one-step results; full set of time dummies included;'Sargan' is a Sargan-Hansen test of the overidentifying restrictions (p-value reported); 'Cash Flow terms' is a Wald Test of the joint significance of the two cash flow terms (p-value reported); 'LM (k)' is the test statistic for the presence of $\mathrm{k}$-th order serial correlation in the first-differenced residuals, distributed $\mathrm{N}(0,1)$ under the null; in column (1) instruments are $y_{t-3}$ to $y_{t-6}$ and $\mathrm{r}_{t-3}$ to $\mathrm{r}_{t-6}$ in the differenced equations and $\Delta y_{t-2}$ and $\Delta \mathrm{r}_{t-2}$ in the levels equations; in column (2) we also include $\mathrm{C}_{t-3} / \mathrm{K}_{t-4}$ to $\mathrm{C}_{t-6} / \mathrm{K}_{t-7}$ in the differenced equations and $\Delta\left(\mathrm{C}_{t-2} / \mathrm{K}_{t-3}\right)$ in the levels equations; in column (3) we use $y_{t-2}$ to $y_{t-6}$ and $\mathrm{r}_{t-2}$ to $\mathrm{r}_{t-6}$, in the differenced equations and $\Delta y_{t-1}$ and $\Delta \mathrm{r}_{t-1}$ in the levels equations; in column (4) we also include $\mathrm{C}_{t-2} / \mathrm{K}_{t-3}$ to $\mathrm{C}_{t-6} / \mathrm{K}_{t-7}$ in the differenced equations and $\Delta\left(\mathrm{C}_{t-1} / \mathrm{K}_{t-2}\right)$ in the levels equations. 
We then consider adding cash flow terms to this basic specification. Notice that our preferred measure of cash flow for the R\&D performing companies is cash flow net of $R \& D$ expenditures. We found this measure to be more informative about the investment behaviour of British companies than cash flow gross of $R \& D$ costs. ${ }^{20}$ As we discuss further below, this is consistent with our view that most of the R\&D budget is regarded as a pre-committed expenditure, not sensitive to short run fluctuations in the firm's financial position, rather than as a potential source of finance for fixed investment.

Columns (2) and (5) then go on to include these cash flow terms. A clear difference emerges in these results insofar as the cash flow terms are jointly significant for Britain but are insignificant at conventional levels for Germany (see the Wald test at the base of the columns). ${ }^{21}$ Relaxing the constant returns to scale assumption by including an additional term in the level of output was unnecessary as the variable was insignificant (coefficients (standard errors) on the second lag of output were 0.007(0.013) in the UK and 0.011(0.010) in Germany). Even in the more general non constant returns models cash flow was still an informative indicator for investment in UK firms, but not in German firms. Finally we drop current cash flow in columns (3) and (6). Again, the cash flow term is significant at conventional levels only for the UK firms.

Turning to the $\mathrm{R} \& \mathrm{D}$ results contained in Table 5 , the error correction terms are again correctly signed, but determined with less precision in Germany than in the UK. Another important difference is that unlike the fixed investment equations cash flow is insignificant in both the British and German sample. Again, the results reported here use cash flow net of R\&D costs. Similar results were found in the R\&D equations for cash flow measured gross of R\&D expenses ${ }^{22}$. A natural interpretation of this

\footnotetext{
${ }^{20}$ Neither measure was informative for German companies.

${ }^{21}$ This is consistent with the evidence presented in Bond et al (1997), using a smaller sample of German firms that are quoted on the stock market (publicly traded Aktiengesellschaften).

${ }^{22}$ We were concerned that although adding R\&D back into cash flow (gross cash flow) is more theoretically satisfactory it would generate a strong positive endogeneity bias as R\&D would appear on both left and right hand side of the estimated equation.
} 
is that transitory cash flow movements are unlikely to have an important impact on a firm's $R \& D$ expenditures, which are largely committed someway in advance. The diagnostics revealed evidence of more persistent serial correlation in the residuals in the UK equations implying that it is necessary to use longer lags of the instruments than in Table $4 .^{23}$ This is why there are fewer observations for the UK sample in this table as we lose one extra cross section of data. We experimented with including lagged R\&D in the investment equations and lagged investment in the $\mathrm{R} \& \mathrm{D}$ equations along the lines of Lach and Schankerman (1989) but found these variables to be insignificant ${ }^{24}$.

These results are provocative but open to the criticism that we have focused only on $R \& D$ performing firms. It seems likely that the $R \& D$ performers are a self selected group whose behaviour may be systematically different from other firms. To address this issue we collected additional data on non-R\&D companies in both countries. Comparing these groups of firms is somewhat hazardous as many of the non-R\&D firms are located in low-tech industries where there is simply no opportunity for any firm to do R\&D. To avoid merely picking up differences in industrial structure, rather than differences between $R \& D$ and non-R\&D firms, we focus on 'high tech' industries defined to be those sectors with an above average ratio of $\mathrm{R} \& \mathrm{D}$ to sales. ${ }^{25}$ We re-estimated the fixed investment equations on this sample and the results are reported in Table 6 (since some of these firms do no R\&D we cannot, of course, estimate the $R \& D$ equations).

\footnotetext{
${ }^{23}$ If we ignore this misspecification problem and use the invalid t-2 instruments, the cash flow terms become jointly significant in the UK equation $\left(\chi^{2}(2)=7.404\right)$ and the error correction term appears to be insignificant $(0.015(0.043))$. In Germany if we drop the t-2 instruments, cash flow remains insignificant $\left(\chi^{2}(2)=1.387\right.$ with a p-value of 0.50$)$.

${ }^{24}$ Other UK studies find mixed results in this regard. Neither Toivanen and Stoneman (1998) or Nickell and Nicolitsas (1996) find significant evidence of firm level R\&D effects on investment as Lach and Shankerman (1989) did. The former paper claims to identify some effect of lagged investment on $\mathrm{R} \& \mathrm{D}$, however, and the latter paper produces evidence for the importance of industry level $\mathrm{R} \& \mathrm{D}$ on firm level investment.

${ }^{25}$ Industries were chosen based on median R\&D to sales intensity. The sample includes aircraft, chemicals, drugs, electrical machinery, non-electrical machinery, vehicles, office and computing equipment, transport equipment, peroleum refineries and products, rubber and plastics, radio and TV equipment and instruments.
} 
Again we observe that cash flow is significant in the UK investment equation (column 1), but not in the German investment equation (column 4). Column (2) then allows the cash flow effect to be different for the firms who perform any R\&D compared to the firms who do not $(\mathrm{R} \& \mathrm{D}=0)$. Interestingly, there appears to be evidence that cash flow has a greater impact on investment for the non-R\&D performers than for the R\&D performers. ${ }^{26}$ Moving to a more parsimonious model in column (3) where we drop some of the insignificant terms confirms that this difference is indeed statistically significant. In Germany, by contrast, cash flow remains insignificant for all samples that we examine (although the sum of the point estimates on cash flow are larger for the non-R\&D performers). The preferred model for Germany is that in column (6) where the cash flow terms are excluded altogether. ${ }^{27}$

Our interpretation of these results is that British firms are subject to significant financial constraints whereas German firms appear not to be. Although clear from the basic investment equations, this difference is not revealed in the $\mathrm{R} \& \mathrm{D}$ equations because the main point at which financial constraints bite is in the decision to engage in $R \& D$, rather than how much to spend in existing $R \& D$ programmes. The $R \& D$ performing firms in the UK are a self selected group who choose to make long term commitments to R\&D programmes, partly on the basis that they do not expect to be seriously affected by financial constraints - this is why cash flow tends to matter less for these firms' investment decisions than for other UK companies.

This interpretation is open to a large number of objections, which are addressed in the next section.

\footnotetext{
${ }^{26}$ Notice that we do not include the $R \& D$ status interaction with cash flow in the instrument set because of the potential endogeneity of $R \& D$ status. The results are little changed, however, were we to include it. For example, including the interaction term in column (3) leaves us with a linear cash flow coefficient (standard error) of $0.245(0.102)$ and an a coefficient (standard error) on the interaction of cash flow and non-R\&D status of $0.460(0.144)$.

${ }^{27}$ In Britain the Wald test of the joint significance of the two terms in cash flow dropped in moving from column (2) to column (3) is $\chi^{2}(2)=0.906$. In Germany the Wald test for all four cash flow terms dropped between columns (5) and $(6)$ is $\chi^{2}(4)=7.320$ with an associated p-value of 0.12 .
} 
Table 6: Fixed Investment Equations - R\&D and non R\&D Performers in High Tech Industries

\begin{tabular}{lcccccc}
\hline \hline & $(1)$ & $(2)$ & $(3)$ & $(4)$ & $(5)$ & $(6)$ \\
$I_{t} / K_{t-1}$ & & & & & & \\
& & $U K$ & & \multicolumn{3}{c}{ Germany } \\
$I_{t-1} / K_{t-2}$ & 0.0002 & -0.007 & -0.037 & 0.072 & 0.068 & 0.092 \\
$\Delta y_{t}$ & 0.070 & 0.054 & 0.067 & 0.072 & 0.071 & 0.046 \\
& 0.271 & 0.266 & 0.292 & 0.141 & 0.156 & 0.012 \\
$\Delta y_{t-1}$ & 0.095 & 0.101 & 0.099 & 0.062 & 0.078 & 0.060 \\
& 0.031 & 0.049 & 0.054 & 0.108 & 0.114 & 0.086 \\
$\mathrm{C}_{t} / \mathrm{K}_{t-1}$ & 0.088 & 0.086 & 0.093 & 0.054 & 0.057 & 0.024 \\
& 0.311 & 0.079 & - & -0.231 & -0.211 & - \\
$\mathrm{C}_{t-1} / \mathrm{K}_{t-2}$ & 0.159 & 0.176 & & 0.180 & 0.160 & \\
& 0.146 & 0.188 & 0.183 & 0.060 & 0.043 & - \\
$(\mathrm{R} \& \mathrm{D}=0)^{*} \mathrm{C}_{t} / \mathrm{K}_{t-1}$ & 0.135 & 0.153 & 0.107 & 0.135 & 0.140 & \\
& - & 0.674 & 0.662 & - & -0.191 & - \\
$(\mathrm{R} \& \mathrm{D}=0)^{*} \mathrm{C}_{t-1} / \mathrm{K}_{t-2}$ & & 0.298 & 0.221 & & 0.478 & \\
& - & -0.177 & - & - & 0.347 & - \\
$(\mathrm{k}-\mathrm{y})_{t-2}$ & & 0.340 & & & 0.564 & \\
& -0.072 & -0.084 & -0.089 & -0.064 & -0.066 & -0.061 \\
& 0.069 & 0.069 & 0.077 & 0.053 & 0.051 & 0.023 \\
\hline Sargan (p) & & & & & & \\
Cash Flow -linear (p) & 0.555 & 0.833 & 0.827 & 0.704 & 0.663 & 0.578 \\
Cash Flow -interaction (p) & 0.002 & 0.170 & 0.087 & 0.214 & 0.306 & - \\
LM (1) & - & 0.051 & 0.003 & - & 0.828 & - \\
LM (2) & -4.474 & -4.678 & -4.277 & -4.715 & -4.833 & -4.017 \\
Observations & 0.576 & 0.996 & 0.665 & -1.526 & -1.569 & -1.493 \\
Firms & 1107 & 1107 & 1107 & 800 & 800 & 800 \\
\hline \hline & 263 & 263 & 263 & 246 & 246 & 246 \\
\hline
\end{tabular}

NOTES:- Asymptotically robust standard errors are reported below coefficients; UK results are in columns (1) - (3), German results in columns (4) - (6); estimation by GMM-SYSTEM using DPD98 package one-step results; full set of time dummies included; instrument set the same as Table 4 columns (2) and (5) in columns (1) and (4) respectively. $R \& D=0$ if firm does not perform any R\&D. 
Table 7: Horse Races - R\&D Status vs. Size

\begin{tabular}{|c|c|c|c|c|}
\hline \multirow{2}{*}{$\begin{array}{l}\mathrm{I}_{t} / \mathrm{K}_{t-1} \\
I_{t-1} / K_{t-2}\end{array}$} & \multicolumn{2}{|c|}{ UK } & \multicolumn{2}{|c|}{ Germany } \\
\hline & $\begin{array}{l}-0.008 \\
0.077\end{array}$ & $\begin{array}{c}-0.004 \\
0.071\end{array}$ & $\begin{array}{l}0.085 \\
0.080\end{array}$ & $\begin{array}{l}0.073 \\
0.071\end{array}$ \\
\hline$\Delta y_{t}$ & $\begin{array}{l}0.232 \\
0.102\end{array}$ & $\begin{array}{l}0.239 \\
0.097\end{array}$ & $\begin{array}{l}0.149 \\
0.080\end{array}$ & $\begin{array}{l}0.147 \\
0.074\end{array}$ \\
\hline$\Delta y_{t-1}$ & $\begin{array}{l}0.025 \\
0.080\end{array}$ & $\begin{array}{l}0.014 \\
0.087\end{array}$ & $\begin{array}{l}0.100 \\
0.059\end{array}$ & $\begin{array}{l}0.112 \\
0.054\end{array}$ \\
\hline$(\mathrm{k}-\mathrm{y})_{t-2}$ & $\begin{array}{r}-0.056 \\
0.065\end{array}$ & $\begin{array}{r}-0.049 \\
0.067\end{array}$ & $\begin{array}{c}-0.049 \\
0.059\end{array}$ & $\begin{array}{r}-0.067 \\
0.050\end{array}$ \\
\hline $\mathrm{C}_{t} / \mathrm{K}_{t-1}$ & $\begin{array}{l}0.342 \\
0.231\end{array}$ & $\begin{array}{l}0.541 \\
0.254\end{array}$ & $\begin{array}{l}0.086 \\
0.437\end{array}$ & $\begin{array}{r}-0.251 \\
0.398\end{array}$ \\
\hline $\mathrm{C}_{t-1} / \mathrm{K}_{t-2}$ & $\begin{array}{l}0.252 \\
0.148\end{array}$ & $\begin{array}{l}0.246 \\
0.163\end{array}$ & $\begin{array}{l}0.505 \\
0.423\end{array}$ & $\begin{array}{l}0.401 \\
0.315\end{array}$ \\
\hline$(\mathrm{R} \& \mathrm{D}=0) *\left(\mathrm{C}_{t} / \mathrm{K}_{t-1}\right)$ & $\begin{array}{l}0.678 \\
0.357\end{array}$ & - & $\begin{array}{c}-0.583 \\
0.790\end{array}$ & - \\
\hline$(\mathrm{R} \& \mathrm{D}=0)^{*}\left(\mathrm{C}_{t-1} / \mathrm{K}_{t-2}\right)$ & $\begin{array}{r}-0.082 \\
0.370\end{array}$ & - & $\begin{array}{l}0.148 \\
0.717\end{array}$ & - \\
\hline$(\mathrm{SMALL}) *\left(\mathrm{C}_{t} / \mathrm{K}_{t-1}\right)$ & $\begin{array}{r}-0.351 \\
0.279\end{array}$ & $\begin{array}{l}0.297 \\
0.269\end{array}$ & $\begin{array}{l}-0.239 \\
0.452\end{array}$ & $\begin{array}{l}0.093 \\
0.321\end{array}$ \\
\hline$(\mathrm{SMALL}) *\left(\mathrm{C}_{t-1} / \mathrm{K}_{t-2}\right)$ & $\begin{array}{l}0.086 \\
0.189\end{array}$ & $\begin{array}{r}-0.107 \\
0.186\end{array}$ & $\begin{array}{l}-0.508 \\
0.445\end{array}$ & $\begin{array}{r}-0.426 \\
0.366\end{array}$ \\
\hline Sargan (p-value) & 0.873 & 0.552 & 0.625 & 0.559 \\
\hline SMALL interactions(p-value) & 0.290 & 0.362 & 0.268 & 0.360 \\
\hline Cash Flow linear (p-value) & 0.022 & - & 0.393 & - \\
\hline $\mathrm{R} \& \mathrm{D}=0$ interactions ( $\mathrm{p}$-value) & 0.084 & - & 0.687 & - \\
\hline LM (1) & -4.424 & -4.334 & -4.714 & -4.758 \\
\hline LM (2) & 1.553 & 1.221 & -1.515 & -1.584 \\
\hline Observations & 1107 & 1107 & 800 & 800 \\
\hline Firms & 263 & 263 & 246 & 246 \\
\hline
\end{tabular}

NOTES:- Same equation as Table 6 columns (2) and (5); SMALL $=1$ if the firm has below median sample real sales. $R \& D=0$ if firm does not perform any $R \& D$. 


\section{Further Investigations}

In this section we consider several challenges to the robustness and interpretation of our results. In particular we investigate whether $\mathrm{R} \& \mathrm{D}$ status proxies for size differences; whether R\&D status is related to cash flow; whether cash flow is proxying for demand expectations; evidence on the rate of return to $\mathrm{R} \& \mathrm{D}$ from production functions; and a host of (mis) measurement issues.

\subsection{Firm Size and Cash Flow}

Does the $R \& D$ vs. non $R \& D$ sample split merely reflect differential firm size? $R \& D$ performing firms were shown to be much larger than non-R\&D performing firms in Section 2 , so the fact that cash flow matters less for $\mathrm{R} \& \mathrm{D}$ performers could simply reflect the fact that they are larger. Columns (1) and (3) of Table 7 mimic the most general specification of Table 6 but includes extra interactions with firm size. Small firms are defined as having real sales less the country-specific sample median. In both countries there is no evidence that there is a significantly positive interaction between cash flow and size. In Britain the interaction is insignificant and in Germany the interaction is incorrectly signed (negative) ${ }^{28}$. These results are quite robust to dropping the interactions with R\&D status (see columns (2) and (4)), choosing other ways to define size (such as initial employment) or including the size interactions in the instrument set. We also tried including other interactions with $R \& D$ status to see if there were any other systematic differences in the effects of variables apart from cash flow for the non-R\&D performers. All the other interactions were insignificant. ${ }^{29}$

\footnotetext{
${ }^{28}$ The negative sign on the interaction for Germany in quite surprising, although it should be remembered that the 'small' firms in the data are not usually regarded as small by conventional standards. From Table 2 we see that median firm size is well over 1000 employees for each country.

${ }^{29}$ For example, in the context of column (2) of Table 6 , a Wald test of the joint significance of a full set of interactions of the time dummies with R\&D status (to check for differential response to the business cycle) gave a Wald statistic of $\chi^{2}(7)=9.711$ with an associated p-value of 0.206. An interaction with the error correction term and $\mathrm{R} \& \mathrm{D}=0$ status had a coefficient of -0.111 with a standard error of 0.073
} 


\subsection{Direct evidence from $R \& D$ status probits}

An implication of our interpretation that cash flow affects the $R \& D$ participation equation rather than the $R \& D$ spending equation, is that a firm is more likely to set up an $R \& D$ programme if it has (and expects to have) strong cash flow. It is difficult to directly test this hypotheses as very few firms are observed to change R\&D status in our dataset. This is partially because we concentrate on large firms and partially because transitions between $R \& D$ status come through company entry and exit which we do not explicitly model. ${ }^{30}$ The infrequency of transitions from $\mathrm{R} \& \mathrm{D}$ to non-R\&D status is nevertheless consistent with our view that engaging in R\&D implies a long term commitment to financing an inflexible R\&D budget.

Table 8 offers some evidence on this issue by reporting a probit model for R\&D status as a function of lagged cash flow, lagged sales (to proxy size) and industry dummies. In order not to inflate the precision of the estimates we do this for one cross section in 1992 (where we have a large number of firms - similar patterns emerge taking other years).

Firm size is correlated with a greater probability of conducting $R \& D$ in both countries, as one would expect. More importantly, lagged cash flow is strongly and significantly correlated with whether a firm performs any R\&D in Britain, but not in Germany. ${ }^{31}$ In Britain it is also possible to include financial structure variables available on the balance sheet. The lagged ratio of debt to capital takes a significantly negative coefficient when added to the probit model for the UK (-1.548 with a standard error of 0.514 ) but the cash flow term remains significantly positive (1.366 with a standard error of 0.576$)$.

These results are consistent with our view that UK firms that are more likely to

\footnotetext{
${ }^{30}$ We are implicitly assuming that the inclusion of fixed effects is sufficient to control for selectivity problems.

${ }^{31}$ Evaluating the marginal effect of cash flow on R\&D status at sample means reinforces this conclusion. The marginal effect in Britain is 0.404 and in Germany is 0.000008 .
} 
be affected by financing constraints (i.e. those with low profitability and/or high debt) are less likely to participate in $\mathrm{R} \& \mathrm{D}$. Of course, they may also reflect reverse causation, with high profitability being the result of successful R\&D. But if this is the case it is puzzling that a similar relationship is not observed in Germany.

Table 8: Probits for R\&D Performance in high tech industries

\begin{tabular}{lcccc}
\hline \hline R\&D $>0$ & $(1)$ & $(2)$ & $(3)$ & $(4)$ \\
& UK & Germany & UK & UK \\
& & & & \\
$\mathrm{C}_{t-1} / K_{t-2}$ & 1.098 & 0.068 & 2.864 & 3.100 \\
& 0.535 & 0.974 & 1.216 & 1.550 \\
$y_{t-1}$ & 0.477 & 3.853 & 0.272 & 0.277 \\
& 0.178 & 1.119 & 0.183 & 0.186 \\
$(\widehat{V} / K)_{t-1}$ & & & & -0.056 \\
& & & & 0.226 \\
Industry dummies & yes & yes & yes & yes \\
Log L & -118.02 & -77.18 & -46.43 & -46.39 \\
Pseudo R & 0.184 & 0.223 & 0.230 & 0.230 \\
Observations & 212 & 218 & 94 & 94 \\
Firms & 212 & 218 & 94 & 94 \\
\hline \hline
\end{tabular}

NOTES:-The coefficients and standard errors are taken from probit ML estimates of whether a firm performed $R \& D$ in 1992 . These are estimated for high $R \& D$ industries only. The final two columns conditions on the sample of firms where we also have analysts' forecasts available to construct a predicted Tobin's Q $(\widehat{V} / K)$.

\subsection{Is Cash Flow proxying differential demand expectations?}

A major problem with using cash flow to proxy liquidity constraints is that the interpretation of cash flow is ambiguous. As we emphasized in Section 3.1 cash flow could be proxying expectations of future demand. We test the magnitude of this problem in two distinct ways. First, following Bond and Cummins (2001) we construct a "pseudo Q" measure of Tobin's average Q based on analysts' forecasts of future earnings. Bond 
and Cummins (2001) find that when Q is specified in this way, it drives out current and past cash flow from investment equations. This is probably because the numerator of Q appears to be much more informative about the fundamental value of the firm when based on analysts forecasts than on noisily measured stock market prices.

Unfortunately, analysts' forecasts are only available for about half of the firms in our UK data (and not at all for Germany). Column (3) of Table 8 shows that the results hold up on this smaller sample - cash flow remains significantly positively associated with R\&D performance. Column (4) includes the pseudo Q measure of future profitability. The point estimate is negative and insignificant and the cash flow variable remains significant. We conclude that the cash flow variable in not simply picking up differential demand in the R\&D participation equation.

The second method for looking at whether cash flow simply proxies future demand this is to examine forecasting equations for real sales (Table 9). Of particular interest is the question whether cash flow is a more informative predictor of future sales in the UK than Germany. This would undermine our interpretation that the significance of the cash flow terms in the UK investment equation (but not in the German investment equation) reflects evidence for liquidity constraints in Britain.

The UK results are in Column (1) of Table 9 and should be compared with column (3) which has the equivalent real sales equations for Germany. We estimate a $\operatorname{VAR}(2)$ specification using all the variables included in the investment models (we also estimated $\operatorname{VAR}(1)$ and $\operatorname{VAR}(3)$ models with similar results). Although past cash flow is positively correlated with real sales, the cash flow terms are not jointly significant in the UK real sales equation. ${ }^{32}$ In Germany, by contrast, cash flow plays more of a role in predicting future demand. This result flatly contradicts the idea that the significance of cash flow in the UK investment equation is picking up differential demand expectations.

\footnotetext{
${ }^{32}$ The other variables do a better job at forecasting future demand than cash flow. For example, in the UK the cash flow terms become jointly significant if we drop the lagged investment rates from the sales regression ( $\mathrm{p}$-value 0.0004 ).
} 
Furthermore, the importance of cash flow in Germany is somewhat reassuring. It could be argued that the absence of cash flow effects in Germany is driven by attenuation bias arising from greater measurement error in the German sample. If this was the case it is unlikely that German cash flow would do a good job of forecasting future demand. ${ }^{33}$

Columns (2) and (4) in Table 9 show the results for a more general model where the coefficients of the right hand side variables are allowed to vary by R\&D status. The idea here is to investigate whether the stronger cash flow effects in the UK non-R\&D sample may be driven by the fact that cash flow is more informative in predicting future demand for firms who do not perform R\&D. Again, in the UK the correlation is mildly positive, but insignificant. In Germany the coefficients on cash flow are incorrectly signed. Dropping all the interactions except the cash flow interactions does not alter the results - the cash flow variables remain insignificant ${ }^{34}$.

We conclude that the results reported in the previous section cannot be explained by systematic differences in the informativeness of cash flow in forecasting future real sales growth.

\subsection{Evidence on rates of returns from Production Functions}

One implication of our claim that British firms are subject to greater financial constraints than German firms is that, at the margin, we might expect investment and R\&D projects to earn a higher return in Britain than in Germany. ${ }^{35}$ An alternative ra-

\footnotetext{
${ }^{33}$ Related to this, we also considered simple reduced form models for investment, in which current investment was related to its own lags and current and lagged cash flow terms only (i.e. omitting all sales terms from our preferred specifications). In this case we found positive and significant effects from cash flow in both countries.

${ }^{34}$ Although the theoretical model has expected sales as the main observable driving force of investment, it may be that we are omitting determinants of future profitable opportunities. In this sprit we also replicated all specifications in Table 9 using cash flow instead of sales as the dependent variable. Like sales, lagged cash flow is no better at predicting future cash flow for non-R\&D firms relative to $R \& D$ firms in either country. Cash flow significantly predicts future cash flow almost as well for Germany as for the UK (sum of lagged coefficients are 0.74 and 0.81 respectively).

${ }^{35}$ This would not necessarily follow if all R\&D in Britain were performed by an unconstrained subset of firms.
} 
tionalisation of the lower $R \& D$ intensities in Britain is that British $R \& D$ is simply less productive than German R\&D. To pursue this we estimated production functions for Britain and Germany and calculated the implied marginal rates of return. Full results are given in Bond, Harhoff and Van Reenen (2003). Dynamic Cobb-Douglas production functions were estimated for both countries. Real sales were allowed to depend on capital, labor and R\&D (following inter alia Griliches, 1986). The data and econometric methodology are essentially identical to that utilized in this paper. We found that we could always reject the hypothesis that Germany had a higher elasticity of output with respect to R\&D than the UK. Calculating the implied marginal rates of return is extremely hazardous, especially across countries. ${ }^{36}$ Nevertheless, on the assumption that depreciation rates and double counting problems are similar across countries, our estimates of the gross excess rates of return to $R \& D$ were universally higher in Britain than in Germany. This came from a combination of the fact that the estimated elasticities of output with respect to $R \& D$ were higher in Britain (0.10 compared to 0.08 in our preferred models) and the fact that $R \& D$ intensity is lower in Britain than in Germany. A similar pattern occurs for fixed capital, the elasticities being 0.36 in the UK and 0.30 in Germany. This is consistent with investors requiring a higher hurdle rate for an identical project in Britain relative to Germany, possibly as a result of a higher cost premium for external sources of finance.

\footnotetext{
${ }^{36}$ See the discussions in Griliches and Mairesse (1983, 1990).
} 
Table 9: VAR Forecasting Equations for real sales in high R\&D industries

\begin{tabular}{|c|c|c|c|c|c|c|}
\hline \multirow{3}{*}{$\mathrm{y}_{t}$} & \multicolumn{3}{|c|}{$\overline{\mathrm{UKK}}$} & \multicolumn{3}{|c|}{ GERMANY } \\
\hline & (1) & \multicolumn{2}{|r|}{ (2) } & (3) & \multicolumn{2}{|c|}{ (4) } \\
\hline & Linear & Linear & $\begin{array}{c}(\mathrm{R} \& \mathrm{D}=0) \\
\text { interactions }\end{array}$ & Linear & Linear & $\begin{array}{l}\mathrm{R} \& \mathrm{D}=0 \\
\text { nteractions }\end{array}$ \\
\hline \multirow[t]{2}{*}{$C_{t-1} / K_{t-2}$} & 0.142 & 0.057 & 0.232 & 0.276 & 0.287 & -0.016 \\
\hline & 0.088 & 0.098 & 0.172 & 0.104 & 0.115 & 0.274 \\
\hline \multirow[t]{2}{*}{$\mathrm{C}_{t-2} / K_{t-3}$} & -0.079 & -0.035 & -0.133 & -0.136 & -0.089 & -0.387 \\
\hline & 0.080 & 0.094 & 0.160 & 0.095 & 0.103 & 0.271 \\
\hline \multirow[t]{2}{*}{$\mathrm{y}_{t-1}$} & 1.039 & 1.041 & -0.019 & 0.775 & 0.772 & -0.032 \\
\hline & 0.047 & 0.069 & 0.088 & 0.073 & 0.078 & 0.172 \\
\hline \multirow[t]{2}{*}{$\mathrm{y}_{t-2}$} & -0.047 & -0.053 & 0.028 & 0.224 & 0.229 & 0.033 \\
\hline & 0.046 & 0.068 & 0.087 & 0.073 & 0.078 & 0.171 \\
\hline \multirow[t]{2}{*}{$\mathrm{I}_{t-1} / \mathrm{K}_{t-2}$} & 0.231 & 0.353 & -0.239 & 0.433 & 0.387 & 0.255 \\
\hline & 0.088 & 0.068 & 0.166 & 0.133 & 0.155 & 0.258 \\
\hline \multirow[t]{2}{*}{$\mathrm{I}_{t-2} / \mathrm{K}_{t-3}$} & -0.020 & -0.042 & 0.057 & -0.051 & 0.005 & -0.230 \\
\hline & 0.050 & 0.059 & 0.098 & 0.112 & 0.124 & 0.269 \\
\hline $\mathrm{R}^{2}$ & 0.991 & \multirow{2}{*}{\multicolumn{2}{|c|}{$\begin{array}{c}0.992 \\
0.20(0.821)\end{array}$}} & 0.994 & \multicolumn{2}{|c|}{0.994} \\
\hline F-test of linear $(C / K)$ terms & $1.66(0.190)$ & & & $3.81(0.023)$ & \multicolumn{2}{|c|}{$4.17(0.016)$} \\
\hline F-test of $(C / K)^{*}(R \mathscr{E} D=0)$ & - & \multicolumn{2}{|c|}{$1.15(0.317)$} & - & \multirow{2}{*}{\multicolumn{2}{|c|}{$\begin{array}{c}2.36(0.095) \\
800\end{array}$}} \\
\hline Observations & 1107 & & 1107 & 800 & & \\
\hline
\end{tabular}

NOTES:- The sample is of firms in high tech industries (same as Table 6); all variables are in levels; a full set of time and industry dummies in all columns; robust standard errors in italics; estimation by OLS . 


\subsection{Other Measurement Issues}

The main concern in this paper is not measurement error per se, but whether the measurement differences between countries may be driving the results rather than any intrinsic institutional differences. There is some further discussion of this in the Data Appendix, but we list here a selection of the major robustness issues we considered.

(a) Pre sample information on investment. We use UK investment data from pre1985 to construct the capital stock whereas it is only available in Germany after 1986 . We re-constructed the capital stock measure in the UK to use only post-1985 information. Similar results were found. For example, in the regressions of Table 6 column (1) the Wald test of the joint significance of the cash flow terms was $\chi^{2}(2)=26.29$.

(b) Definition of Investment. The UK investment data can be used to obtain several measures of a wide (including acquisitions) or narrow (excluding acquisitions) investment series. All specifications were run on these different measures with qualitatively similar results. For example, using the 'narrow definition' of investment and capital which excludes fixed assets purchased through acquisitions gave a coefficient of $0.267(0.128)$ on cash flow in the preferred model of investment for the $\mathrm{R} \& \mathrm{D}$ performers. ${ }^{37}$

(c) Accounting Change. There is a change in UK accounting procedures for the sources and uses of funds account in 1991. Although we believe that a consistent investment series before and after the change can be constructed, we checked this by allowing all variables to take different coefficients before and after the change. All the interactions were individually and jointly insignificant. For example, in column (2) Table 4 the Wald test of the joint significance of the interactions gave a $\chi^{2}(6)=4.11$ with an associated p-value of 0.662 .

\footnotetext{
${ }^{37}$ This is the coefficient on a model identical to that of Table 4 column (3) except we use contemporaneous cash flow instead of lagged cash flow only. This compares with $0.290(0.103)$ for the 'wide' measure used elsewhere in this paper. So there is a slight difference in the preferred dynamic model across the two definitions of capital.
} 
(d) German pensions funds. Unlike their British counterparts, it is not illegal for German firms to draw on their internal pension fund reserves for investment purposes. This could be considered as free cash flow. We also experimented with several different ways of including the increase in pensions reserves in the definition of cash flow for Germany. None of these changed the qualitative nature of the results. For example, replicating the regression in column (4) of Table 6 using the most inclusive definition of cash flow gave coefficients (standard errors) on current and lagged cash flow of $0.192(0.126)$ and $0.091(0.100)$ respectively with a p-value on the Wald test of joint significance of 0.189 .

(e) Consolidation of German accounts. In Germany a few of the companies we analyze may be subsidiaries of larger groups whereas for the UK we only use the consolidated accounts of the parent company. This is only a problem for the sample underlying Table 6 where we draw on non-R\&D firms. Although we never include more than one subsidiary of a group in Germany we want to be sure that the results are robust to the exclusion of these companies. In the event the qualitative results carry over to the sub-sample, although with less precisely determined coefficients (we know with certainty that the accounts are worldwide consolidated for $80 \%$ of German firms). For example, replicating the regression in column (4) of Table 6 gives coefficients on current and lagged cash flow of $-0.117(0.171)$ and $0.089(0.151)$ respectively with a p-value on the Wald test of joint significance of 0.752 .

\section{Conclusions}

This paper has examined the cash flow sensitivity of investment in both fixed capital and R\&D, for samples of firms in Britain and Germany. We argued that the well known institutional differences across the financial systems in these two countries offers a powerful test for the importance of financial constraints for investment in market economies. Despite the common belief that financial constraints cause British firms to 
invest less than their German counterparts, particularly in long-term investments like $\mathrm{R} \& \mathrm{D}$, there is almost no micro-econometric evidence in this area. We have assembled data for essentially all the firms who report R\&D in Britain and Germany since the mid 1980s and test the hypothesis that British firms are more likely to face financial constraints than German firms.

Our results are easily summarised. Cash flow matters for the fixed investment of British firms, but not German firms. In neither country does cash flow appear to be important for the flow of $\mathrm{R} \& \mathrm{D}$ spending. In Britain cash flow matters more for the fixed investment decisions of non-R\&D firms than it does for $R \& D$ firms, and there is a significant correlation between cash flow and whether or not a firm performs R\&D. We interpret this set of results as suggesting that UK firms face a higher wedge between the costs of external and internal finance than German firms. Thus they are more cautious about undertaking long term commitments to R\&D projects than their German counterparts, and those British firms that choose to do R\&D are a self-selected sample with 'deep pockets', for whom financial constraints are less likely to be binding. Our basic findings held up when subjected to a battery of robustness tests including explicit estimation of forecasting equations for sales, R\&D status equations (including analysts' forecasts) and production functions.

There are of course numerous problems and criticisms still remaining. The macroeconomic turbulence induced by such events as German re-unification in 1989 and British exit from the European Exchange Rate Mechanism in 1992 may make this sample period unusual. From our perspective, these events provide a number of exogenous shocks to the financial position faced by our companies and are therefore a useful source of exogenous variation. It may be, however, that future examination in more stable periods will reveal different results. Another criticism is that the distinction between 'German' and 'British' firms is becoming meaningless in a world of increasingly global financial markets. However the systematic differences found here between superficially 
similar large companies in the two countries suggest that national financial systems still matter when it comes to raising finance for long-term investment. Thirdly, our results explain why fewer British firms perform $R \& D$, but they do not explain why even amongst the $R \& D$ performers there are such lower $R \& D$ intensities in Britain compared to Germany. This could be linked to other problems such as differential skills and training patterns across the two countries. Examining different R\&D activities within firms who operate $\mathrm{R} \& \mathrm{D}$ plants in both countries would be extremely useful in examining the importance of these other factors

Finally, although we are confident that we have identified important differences between the two countries, we are still faced with a serious challenge in explaining the exact mechanisms that cause financial constraints to be more significant in the UK. Edwards and Fischer (1994), among others, have cast doubt on the importance of long term relationships between banks and firms in Germany. Other potentially important differences relate to the proportion of companies whose shares are quoted (and actively traded) on stock exchanges, the concentration of share ownership and the monitoring role played (or not played) by institutional shareholders, the level and flexibility of dividend payout ratios, and the effects of hostile takeover activity. Identifying which (if any) of these factors are the root cause of differences in the impact of financing constraints on firms' investment activities will be a priority in our future research. 


\section{Appendix I: Data}

\section{Germany}

The German dataset contains information on manufacturing firms from three major sources: financial accounts data (balance sheets and profit and loss accounts) from Hoppenstedt (commercial suppliers of databases) and Creditreform (a large credit rating agency), and R\&D expenditure data collected from the Bundesanzeiger, the official bulletin of the German government. The data are available from 1987 onwards, since earlier data are not directly comparable due to accounting regulatory changes. In 1985, several changes were introduced into German corporate law (§289 Handelsgesetzbuch), most of them triggered by the European Community's Fourth Company Law directive on harmonization of national requirements pertaining to financial statements. Thus starting in the fiscal year of 1987, all Gesellschaften mit beschränkter Haftung (GmbHs, limited liability corporations) and Aktiengesellschaften (AGs, stock-based corporations) had to submit their annual financial statements to the Commercial Register. Only the larger firms have to have their statements audited, smaller ones need not submit a statement of profits and losses, and the balance sheet can be abbreviated significantly. Mediumsized and large firms are required to publish their statements in the Bundesanzeiger. The size requirements are satisfied if two or more of the following conditions are met: revenues in excess of DM 32 million, more than 250 employees, or balance-sheet total in excess of DM 15 million.

A discussion of the situation of the business (Lagebericht) is part of the published statement. Besides establishing new publication requirements, the 1985 law also requires firms to comment on their R\&D activities ( $\$ 289$ Handelsgesetzbuch, para 2).

The data used in this paper originate with financial statements and respective appendices published in the Bundesanzeiger. To obtain the respective data, the 1993 
volume of the Bundesanzeiger was searched for any published statements that indicated R\&D activities. These roughly 900 records provided the "master list" of companies for the data collection. The statements of these companies were then tracked backwards to 1987 and forward to 1994. Whenever companies provided quantitative items on their $\mathrm{R} \& \mathrm{D}$ activities, the record was entered into the database. A list of companies which had published similar information in 1987 was provided by B. Schwitalla and H. Grupp and used to check the completeness of our own data search. See Schwitalla (1993) for a description of the 1987 cross-section.

$R \& D$ Investment $(R)$. Quantitative data on $R \& D$ activity were recorded from the Bundesanzeiger if one or several of the following items were available: i) $R \& D$ expenditures, ii) R\&D employees, iii) $R \& D$ intensity with respect to sales, iv) R\&D intensity with respect to total number of employees, v) growth rates of any of these indicators. For about 200 firms, comparable data from the Mannheim Innovation Panel (MIP) were available for two or more years. The $R \& D$ figures were nearly identical, leaving aside rounding errors in the survey responses. Since the MIP survey explicitly asks for R\&D according to the Frascati definitions, the correspondence between the two sources is reassuring.

Since the operationalisation of the theoretical model requires data on R\&D expenditures, the respective information had to be imputed for a small number of cases for which it was not available directly. In the case of items ii) and iv), industry-specific regression coefficients from a previous analysis of the 1987 and 1989 Stifterverband surveys were used to impute $R \& D$ expenditures from $R \& D$ personnel data. These regression results are available upon request. As one should expect, the number of $R \& D$ employees and $\mathrm{R} \& \mathrm{D}$ expenditures are highly correlated $(\mathrm{r}=0.98)$, and inclusion of time and industry dummies in these regressions generates a good fit.

In addition to the R\&D items, the Bundesanzeiger statements were also used to collect information on investment and capital stocks evaluated at historical costs. The data 
obtained from the Bundesanzeiger were then matched to commercially available balance sheet data published by Creditreform, a large credit rating agency, or Hoppenstedt, a supplier of commercial databases.

The latter two sources were also used to construct a large sample of firms satisfying the publication requirements of the Handelsgesetzbuch, but without information on their R\&D activities. The information whether a firm from this group performs R\&D or not was obtained in telephone interviews with the respective firms (unless matched Bundesanzeiger data clearly indicated that it was active in $R \& D)$. The telephone survey asked firms whether they had a dedicated R\&D laboratory within their enterprise. This definition was chosen to be consistent with our presumption that setting up an R\&D laboratory may entail considerable costs. However, it proved infeasible to obtain detailed R\&D expenditure data for several years in these interviews.

Thus, these steps leave us with three groups of firms for which financial accounts data was available: $R \& D$ performers with $R \& D$ expenditures, $R \& D$ performers with information on R\&D expenditures missing, and firms which definitely did not perform R\&D. In order to have consistent samples when we estimate $R \& D$ investment equations (for which $R \& D$ expenditure data are needed) and investment equations for R\&D performers and firms which do not undertake R\&D, we only used the first and the third group of firms in this paper.

Using ownership information from a variety of sources, all subsidiaries of foreign firms were excluded. Similarly, we excluded all non-independent firms in order to avoid measurement problems caused by transfer pricing etc. The following sections briefly describe the variables and their definitions.

Investment (I). The data on additions to plant, property and equipment came from the detailed Anlagenspiegel tabulation of assets in each of the Bundesanzeiger entries. The tabulation also includes their value at historical cost.

Capital stock $(K)$ was computed by adjusting the historic cost values taken from 
the Anlagenspiegel for inflation, and by applying a perpetual inventory procedure with a depreciation of 8 percent per annum for all years following the first year for which historic cost data were available.

$$
\begin{gathered}
P_{t}^{I} K_{t}=(1-\delta) P_{t-1}^{I} K_{t-1}\left(\frac{P_{t}^{I}}{P_{t-1}^{I}}\right)+P_{t}^{I} I_{t} \\
\text { where : } \begin{cases}K_{t} & : \text { Capital Stock } \\
P_{t}^{I} & : \text { Price of Investment Goods } \\
I_{t} & : \text { Real Investment } \\
\delta & : \text { Depreciation rate }\end{cases}
\end{gathered}
$$

The starting value was based on the net book value of tangible fixed capital assets in the first observation within our sample period, adjusted for previous years inflation. Subsequent values were obtained using accounts data on investment and disposals, national price indices for investment goods prices.

Output (Y). This is simply sales deflated by the aggregate GDP deflator.

Cash Flow (C). For the purpose of the regressions, cash flow is computed as funds available for investment net of $\mathrm{R} \& \mathrm{D}$ spending, i.e. as net income plus depreciation (see the text for discussion of construction cash flow gross of R\&D spending). We also experimented with measures of cash flow which include the firms' internal pension schemes (see section 5.5).

\section{Britain}

The UK data is taken from the accounts of firms listed on the UK stock market whose main area of sales was in the manufacturing industries. This data is contained in the Datastream on-line service.

$R \& D$ investment $(R)$. During the 1980s political pressure built up to improve rates of R\&D disclosure as it did in Germany after the issuing of the European Community's Fourth Company Law directive. Changes began in 1985 in the Companies Consolidated Act of that year, continued in 1987 with the publication of Exposure Draft 41 
committing the authorities to greater regulation and culminated in January 1989 in the Standard Statement of Accounting Practice, SSAP (13) revised. This essentially made reporting of R\&D expenditures "highly recommended" (i.e. practically compulsory for medium and larger firms defined as having satisfied at least two out of the following three criteria: more than 2,500 employees, turnover of at least $£ 80 \mathrm{~m}$ and balance sheet total exceeding $£ 39 \mathrm{~m})$. In the event, disclosure rates rose rapidly throughout the 1980s in expectation of reform and many of the larger R\&D performers had already been disclosing ${ }^{38}$. The original SSAP (13) in 1977 required disclosure only of that portion of $\mathrm{R} \& \mathrm{D}$ which is capitalised. The rules over capitalization are very strict and only a very small fraction of firms capitalise any of their R\&D. When they do it tends to be a very small proportion of their R\&D budget.

The R\&D numbers we use are taken from the company accounts (consolidated group total, DS119). When any R\&D is capitalised that part of the capitalised R\&D that is was written off in that year is included in the R\&D flow measure. We also found our numbers were consistent with the EXSTAT datafile and the R\&D Scoreboard (two other commercial company-level databases).

investment (I). The basic variable used is total new fixed assets. Unlike Germany this includes not only plant, machinery and buildings but also acquisitions of other companies. This is clearly very important in the UK where there are a large number of takeovers and mergers. This was Item DS435 (= DS431+DS432) before 1992. After 1992 we took D1024 and positive values of DS479. Disposals are not included as the series pre-1992 appears to be contaminated by measurement error. To check the robustness of the results we experimented with different definitions of the investment series by (a) including disposals and (b) using the narrower definition of investment to exclude acquisitions. The results are robust to these different definitions and the correlations between the alternative investment series were very high (above 0.95).

\footnotetext{
${ }^{38}$ For an extensive discussion of the probability of disclosure attempt to deal with the selectivity issue see Menezes-Filho, Ulph and Van Reenen (1998) or Belcher (1996).
} 
Capital stock $(K)$ was computed in the same way as in Germany by adjusting the historic cost values taken from the Datastream for inflation, and by applying a perpetual inventory procedure with a depreciation of 8 percent per annum for all years following the first year for which historic cost data were available. When data was available we used 1973 as the starting year.

Output (Y). Sales, Datastream Item 104 deflated by an aggregate producer price index

Cash Flow $(C)$. For the purpose of the regressions, cash flow is computed as funds available for investment, i.e. as net income plus depreciation.

\section{Sample procedures for Both Countries}

Only firms whose main activities where in manufacturing were kept. Non-profit firms and subsidiaries of foreign firms were deleted as well. Firms engaged in large scale merger or takeover activity were either split or dropped from the sample. The dataset is trimmed so that observations were excluded if the following ratios were in the upper or lower percentile of the respective distribution: $\left(I_{t} / K_{t-1}\right),\left(C_{t} / K_{t-1}\right),\left(Y_{t} / K_{t-1}\right)$. The database still contains a small number of nonconsolidated statements for Germany, in particular when comparability over time requires their use (see section 5.5).

Clearly these samples are not representative of the population of firms in either country. They are representative of all the major R\&D performers in each economy, however, accounting for the vast bulk of all R\&D performed. There is a spread of firms across different industries, although it can be seen from Table A2 that Germany has a greater proportion of firms in the machinery sectors than the UK. Note that we have used unbalanced panels (see Table A3) to mitigate survivor bias and the inclusion of fixed effects in all the models should go some way to controlling for selectivity problems. We use two extra years of data in the UK (1985 and 1986) than in Germany to keep the sample sizes roughly comparable (there were fewer UK firms declaring R\&D in the 1987-88 period than Germany before $\operatorname{SSAP}(13)$ took effect). 
Table A1: Industry Breakdown: R\&D Performers

\begin{tabular}{ccccc}
\hline \hline & UK & GER & UK & GER \\
& R\&D/Y & R\&D/Y & \% in Sample & \% in Sample \\
Chemical \& allied industries & 3.3 & 6.6 & $16 \%$ & $21 \%$ \\
Electrical engineering & 5.4 & 7.8 & $19 \%$ & $25 \%$ \\
Mechanical Engineering & 4.0 & 5.6 & $21 \%$ & $27 \%$ \\
Metals & 0.4 & 2.9 & $2 \%$ & $9 \%$ \\
Food, drink, tobacco & 0.5 & 1.3 & $8 \%$ & $2 \%$ \\
Other & 1.2 & 4.4 & $34 \%$ & $16 \%$ \\
\hline \hline
\end{tabular}

Table A2: Industry Breakdown for R\&D and Non-R\&D Performers

\begin{tabular}{lcccc}
\hline \hline & \multicolumn{5}{c}{$\%$ of sample } & \\
Industry & Code & U.K & Germany & 'R\&D' Industry? \\
\hline & $3+5$ & $10 \%$ & $12 \%$ & yes \\
Chemicals (inc. drugs) & 8 & $14 \%$ & $15 \%$ & no \\
Food, Drink, Tobacco & 12 & $8 \%$ & $17 \%$ & yes \\
Non-electical Machinery & 6 & $5 \%$ & $12 \%$ & yes \\
Electrical Machinery & 24 & $11 \%$ & $8 \%$ & no \\
Textiles & 18 & $12 \%$ & $3 \%$ & no \\
Paper and Printing & 15 & $7 \%$ & $1 \%$ & yes \\
Office Equipment (inc. computers) & 11 & $8 \%$ & $5 \%$ & yes \\
Motor Vehicles & 7 & $6 \%$ & $5 \%$ & yes \\
Metal Products & $19 \%$ & $22 \%$ & \\
Others (none with >5\%) & & & \\
& \\
NOTES:- & & \\
Tables A1 and A2 are taken from the samples in 1992. & \\
Firms classified by principal operating industry by sales. \\
\hline \hline
\end{tabular}


Table A3: Balance of Panel

\begin{tabular}{|c|c|c|c|c|}
\hline \multirow[b]{2}{*}{ No of years } & \multicolumn{2}{|c|}{$\overline{R \& D}>0$} & \multicolumn{2}{|c|}{$\overline{\text { High Tech Industries }}$} \\
\hline & UK & GER & UK & GER \\
\hline 3 & 40 & 25 & & \\
\hline 4 & 39 & 28 & 33 & 41 \\
\hline 5 & 68 & 37 & 54 & 39 \\
\hline 6 & 27 & 55 & 29 & 46 \\
\hline 7 & 9 & 46 & 27 & 57 \\
\hline 8 & 6 & 43 & 18 & 63 \\
\hline 9 & 3 & & 33 & \\
\hline 10 & 7 & & 69 & \\
\hline Firms & 199 & 209 & 263 & 246 \\
\hline
\end{tabular}

Table A4 Distribution of observations over years

\begin{tabular}{lllll}
\hline \hline \multirow{2}{*}{ Year } & \multicolumn{2}{l}{ R\&D $>0$} & \multicolumn{2}{l}{ High Tech Industries } \\
& UK & GER & UK & GER \\
1985 & 23 & - & 150 & - \\
1986 & 29 & - & 164 & - \\
1987 & 39 & 129 & 183 & 157 \\
1988 & 44 & 138 & 205 & 175 \\
1989 & 90 & 200 & 224 & 228 \\
1990 & 145 & 214 & 233 & 247 \\
1991 & 168 & 213 & 234 & 255 \\
1992 & 175 & 200 & 225 & 244 \\
1993 & 159 & 175 & 210 & 220 \\
1994 & 114 & 99 & 143 & 129 \\
& & & & \\
Observations & 986 & 1368 & 1971 & 1655 \\
\hline \hline
\end{tabular}

NOTES:- There are more observations here than in the regressions because some cross sections are lost when using lags as right hand side variables and instruments 


\section{References}

[1] Abel, A. and Blanchard, O.J. (1986) 'The Present value of profits and cyclical movements in investment', Econometrica, 54, 249-73

[2] Abel, A. and Eberley, J. (2002) "Q Theory without adjustment costs and cash flow effects without financing cnstraints" University of Pennsylvania mimeo

[3] Arellano, M. and S.R.Bond (1991) 'Some tests of specification for panel data: Monte Carlo evidence and an application to employment equations', Review of Economic Studies, 58.

[4] Arellano, M. and S.R.Bond (1998) 'Dynamic panel data estimation using DPD98: a guide for users', University of Oxford mimeo.

[5] Arellano, M. and Bover, O. (1995) 'Another look at the instrumental-variable estimation of error component models', Journal of Econometrics 68, 29-52.

[6] Bank of England (1996) 'The Financing of Technology based small firms', Occasional Paper.

[7] Bean, C.R. (1981) 'An econometric model of manufacturing investment in the UK', Economic Journal, 91.

[8] Belcher, A. (1996) 'R\&D Disclosure: Theory and Practice', 203-223 in Belcher, A., Hassard, J. and Procter, S. (eds) RESD Decisions, London: Routledge.

[9] Bhagat and Welch (1995) 'Corporate R\&D across countries" Journal of Accounting and Economics

[10] Bloom, N., Chennells, L., Griffith and Van Reenen, J. (1998) 'The Effects of Tax Treatment on the changing cost of R\&D: Evidence from Eight Countries' in Helen 
Lawton-Smith (ed) The Economics of Regulation of High Technology Industries (1998) Oxford: Oxford University Press

[11] Blundell, R. and Bond, S.R. (1998). 'Initial conditions and moment restrictions in dynamic panel data models', Journal of Econometrics, 87, 115-143.

[12] Bond, S., Elston, J., Mairesse, J., Mulkay, B. (1997) 'Financial factors and investment in Belgium, France, Germany and the UK: a comparison using company panel data', Review of Economic and Statistics

[13] Bond, S., Harhoff, D. and Van Reenen, J. (2003) 'R\&D and productivity in Germany and the United Kingdom', IFS mimeo.

[14] Bond, S. and Cummins, J. (2001)"Noisy share prices and the Q model of investment" Institute for Fiscal Studies Discussion Paper No.. W01/22

[15] Bond, S.R. and C.Meghir (1994) 'Dynamic investment models and the firm's financial policy', Review of Economic Studies, 61, 197-222.

[16] Bond, S. and Jenkinson, T. (1996) 'The Assessment: Investment Performance and Policy', Oxford Review of Economic Policy, 12, 2, 1-29.

[17] Cabellero, R. (1998) 'Aggregate Investment', in Taylor, J. and Woodford, M. (eds) Handbook of Macroeconomics, Elsevier.

[18] Cabellero, R., Engel, E. and Haltiwanger, J. (1995) 'Plant-level adjustment dynamics and aggregate investment dynamics' Brookings Papers on Economic Activity 1995 (2): 1-54.

[19] Correia De Silva, L. (1996) 'Dividend payout behaviour of German companies', D.Phil. thesis, University of Oxford. 
[20] Devereux, M.P. and F.Schiantarelli (1990) 'Investment, financial factors and cash flow: evidence from UK panel data', in R.G.Hubbard (ed) Asymmetric Information, Corporate Finance and Investment (University of Chicago Press).

[21] Edwards, J.S and K.Fischer (1994) Banks, Finance and Investment in Germany, Cambridge: Cambridge University Press.

[22] Fazzari, S.M., R.G.Hubbard and B.C.Petersen (1988) 'Financing constraints and corporate investment', Brookings Papers on Economic Policy , 141-195.

[23] Gerschenkron, A. (1968) 'The Modernization of Entrepreneurship', in A. Gerschenkron (ed) Continuity in History and Other Essays Cambridge, MA: Harvard University Press.

[24] Gomes, J. (2001) "Financing Investment" American Economic Review, 91: , $1263-$ 1285

[25] Griliches, Z. (1996) 'Productivity, R\&D and Basic Research at the firm level in the 1970s', American Economic Review, 76, 1, 141-54.

[26] Griliches, Z. and Mairesse, J. (1983) 'Comparing Productivity Growth: An exploration of French and U.S. Industrial Firm Data', European Economic Review 21, 89-119.

[27] Griliches, Z. and Mairesse, J. (1990) 'R\&D and productivity growth: Comparing Japanese and U.S. Manufacturing firms', in Hulten, C. (ed) Productivity Growth in Japan and the United States, Chicago: Chicago University Press.

[28] Hall, B. (2002) "The Financing of Research and Development" NBER Working Paper No. 8773

[29] Hall, B. , Mairesse, J. Branstetter, L., and Crepon , B., (1999) 'Does Cash flow cause investment and R\&D: An exploraton using panel data for French, Japanese 
and United States Firms in teh scientidif sector', in Audretsch, D. and A. Thurik, (eds) Innovation, Industry Evolution and Employment, Cambridge: CUP

[30] Hao, K.Y. and Jaffe, A. (1993) 'Effect of Liquidity on Firms' R\&D Spending', Economics of Innovation and New Technology, 2, 275-282.

[31] Harhoff, D. (1998) 'Are There Financing Constraints for Innovation and Investment in German Manufacturing Firms?', Annales d'Économie et de Statistique, 49/50, 421-456.

[32] Hayashi, F. and Inoue, T. (1991) 'The Relation between firm growth and Q with multiple capital goods: Theory and Evidnce from Panel Data on Japanese Firms', Econometrica, 59, 3, 731-53.

[33] Hoshi, T., A.Kashyap and D.Scharfstein (1991) 'Corporate structure, liquidity and investment: evidence from Japanese industrial groups', Quarterly Journal of Economics, CVI, 33-60.

[34] Himmelberg, C.P. and Peterson, B. (1994) 'R\&D and Internal Finance: A panel data study of small firms in high tech industries', Review of Economics and Statistics, 76(1), 38-51.

[35] Hubbard, R.G. (1990) Asymmetric Information, Corporate Finance and Investment, Chicago: Chicago University Press.

[36] Hubbard, R.G. (1998): 'Capital-Market Imperfections and Investment', Journal of Economic Literature, Vol. XXXVI, 193-225.

[37] Hutton,W. (1995) The State We're In, London: Verso.

[38] Franks, J. and Mayer, C. (1995) 'Ownership and Control', in H. Siebert (ed.) Trends in Business Organisation: Do Participation and Cooperation Increase Competitiveness?, Kiel: Mohr. 
[39] Kaplan, S. and Zingales, L. (1997) 'Do investment - cash flow sensitivies provide useful measures of financing constraints?', Quarterly Journal of Economics CXII, 1, 169-216.

[40] Lach, S. and Shankerman, M. (1989) 'The Dynamics of R\&D Investment in the scientific sector', Journal of Political Economy, 97, 80-904.

[41] Marshall, A. (1919) Industry and Trade, London: Macmillan.

[42] Mayer, C.P. (1990) 'Financial systems, corporate finance and economic development', in R.G.Hubbard (ed) Asymmetric Information, Corporate Finance and Investment, Chicago: University of Chicago Press.

[43] Menezes-Filho, N., Ulph, D. and Van Reenen, J. (1998), 'R\&D investment and union bargaining: Evidence from British companies and establishments', Industrial and Labor Relations Review Vol. 52, No. 1, 45-63 .

[44] Mulkay, Hall and Mairesse (2001) "Investment and R\&D in France and the United States" in Deutsche Bundesbank (ed) Investing Today for the World of Tomorrow, Springer Verlag

[45] Nickell, S.J. (1978) The Investment Decisions of Firms, Cambridge: Cambridge University Press.

[46] Nickell, S.J. (1981) 'Biases in dynamic models with fixed effects', Econometrica, $49,1417-1426$.

[47] Nickell, S.J. (1985) 'Error correction, partial adjustment and all that: An Expository Note', Oxford Bulletin of Economics and Statistics 47, 2, 119-129.

[48] Nickell, S. and Nicolitsas, D. (1996) 'Does Innovation encourage investment in fixed capital?', Centre for Economic Performance Discussion Paper No. 309. 
[49] OECD (1995) DSTI/ANBERD, Paris: OECD.

[50] OECD (1995) Historical Statistics, Paris: OECD.

[51] OECD (1996) Main Science and Technology Indicators, Paris: OECD.

[52] Schumpeter, J. A. (1942) Capitalism, Socialism and Democracy, New York: Harper and Row.

[53] Schiantarelli, F. (1996) 'Financial constraints and investment: a critical survey of the international evidence', Oxford Review of Economic Policy, 12(2).

[54] Schwitalla,B. (1993) Messung und Erklarung industrieller Innovationsaktivitaten, Heidelberg: Physica.

[55] Toivanen, O. and Stoneman, P. (1998) 'Dynamics of R\&D and investment: UK evidence', Economic Letters.

[56] Van Reenen, J. (1997) 'Why has Britain had slower R\&D growth?', Research Policy, $26,493-507$. 


\section{CENTRE FOR ECONOMIC PERFORMANCE \\ Recent Discussion Papers}

594 Andrew B. Bernard Stephen Redding

Peter K. Schott

593 Anthony J. Venables

592 Sylvie Charlot Gilles Duranton

591 Paul Willman

Alex Bryson

Rafael Gomez

590 Marco Manacorda

589 Alex Bryson Rafael Gomez

588 Henry G. Overman L. Alan Winters

587 Pierre-Philippe Combes Henry G. Overman

586 Henry G. Overman

585 A. B. Bernard J. Bradford Jensen P. K. Schott

584 A. B. Bernard J. Bradford Jensen

P. K. Schott

583 S. Wood

S. Moore

582 T. Kirchmaier
Product Choice and Product Switching

Spatial Disparities in Developing Countries: Cities, Regions and International Trade

Communication Externalities in Cities

Why Do Voice Regimes Differ?

Childcare and the Labour Supply of Other Household Members: Evidence from 1920s America

Why Have Workers Stopped Joining Unions?

Trade Shocks and Industrial Location: the Impact of EEC Accession on the UK

The Spatial Distribution of Economic Activities in the European Union

Can We Learn Anything from Economic Geography Proper?

Falling Trade Costs, Heterogeneous Firms and Industry Dynamics

Survival of the Best Fit: Exposure to Low-Wage Countries and the (Uneven) Growth of U.S. Manufacturing Plants

Reviewing the Statutory Union Recognition (ERA 1999)

Corporate Restructuring and Firm Performance of British and German Non-Financial Firms 
581 C. Dougherty

580 S. Burgess

D. Mawson

579 S. Nickell

578 D. Marsden

$577 \quad$ S. Nickell

576 A. de Coulon

M. Piracha

575 H. Steedman

$\mathrm{K}$. Wagner

J. Foreman

574 S. Gibbons

573 R. Griffith

S. Redding

H. Simpson

$572 \quad$ S. Redding

P. K. Schott

571 B. Petrongolo

C. A. Pissarides

570 M. Coles

B. Petrongolo

569 A. Bryson

L. Cappellari

C. Lucifora
Why Is the Rate of Return to Schooling Higher for Women than for Men?

Aggregate Growth and the Efficiency of Labour Reallocation

Poverty and Worklessness in Britain

Renegotiating Performance: the Role of Performance Pay in Renegotiating the Effort Bargain

A Picture of European Unemployment: Success and Failure

Self-Selection and the Performance of Return

Migrants: the Source Country Perspective

The Impact on Firms of ICT Skill-Supply Strategies:

An Anglo-German Comparison

The Costs of Urban Property Crime

Productivity Convergence and Foreign Ownership at the Establishment Level

Distance, Skill Deepening and Development: Will Peripheral Countries Ever Get Rich?

Scale Effects in Markets with Search

A Test Between Unemployment Theories Using Matching Data

Does Union Membership Really Reduce Job

Satisfaction?

To order a discussion paper, please contact the Publications Unit Tel 02079557673 Fax 02079557595 Email info@cep.lse.ac.uk Web site http://cep.lse.ac.uk 